
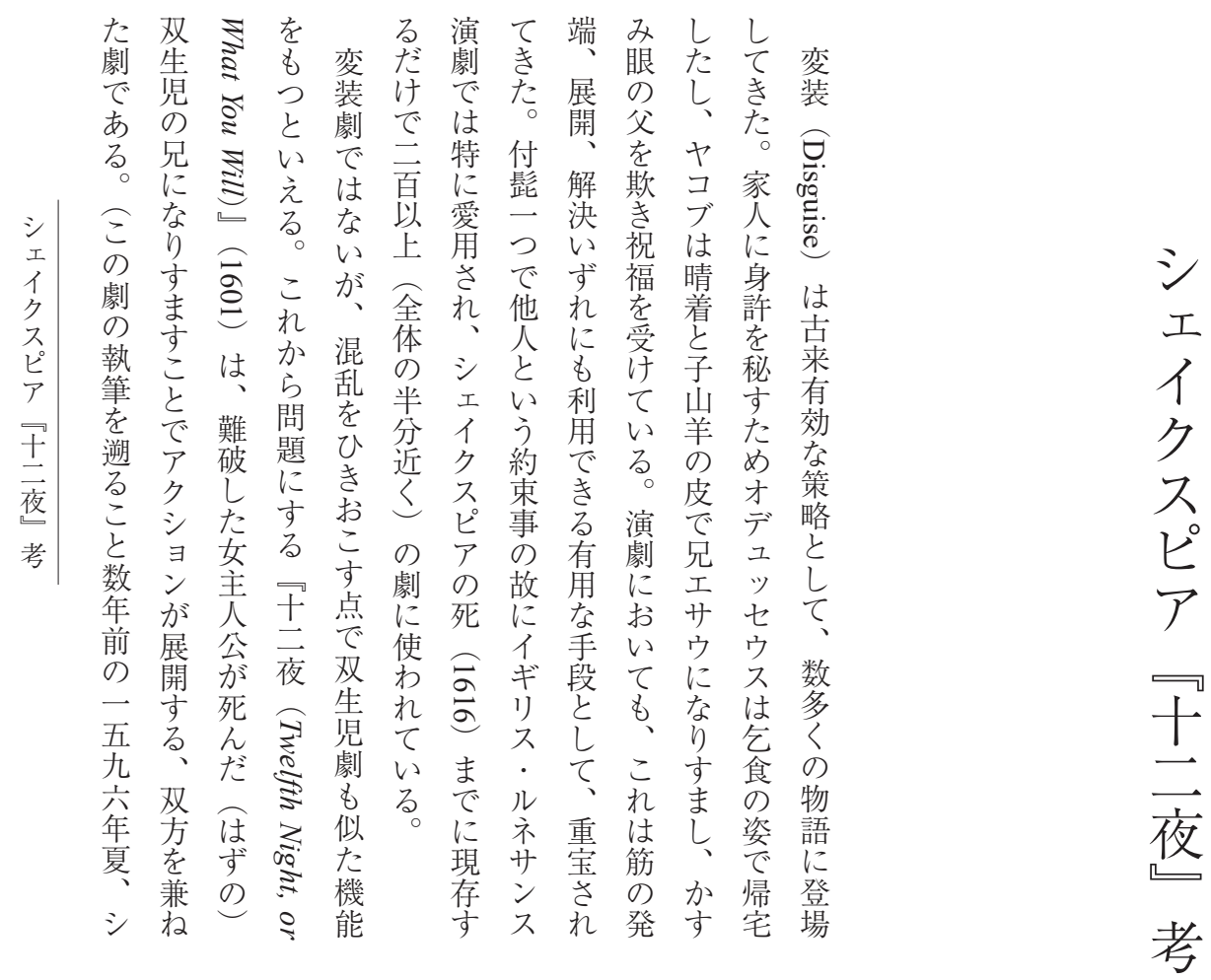

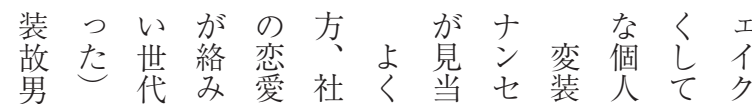
と遊の、劣会は寻箾的い久

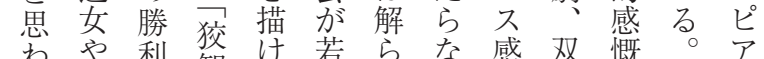
わや利智な若らな感叒慨。死は

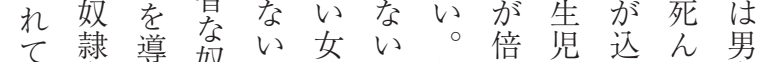

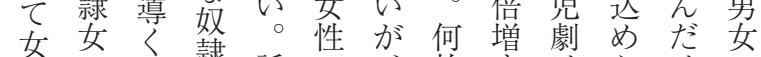
にの。隷話の、故专はらはの 炀身 こ瓦の自口吕ると机ず双

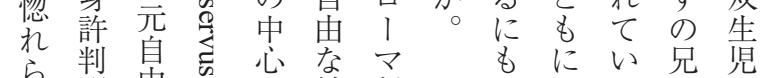
ら明由加劇品た加の

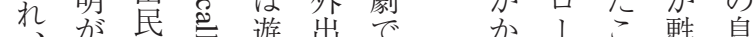

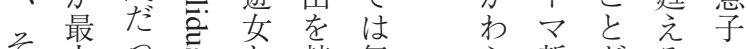
こ奇た氜禁舞占新た る

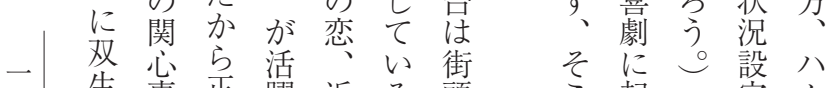

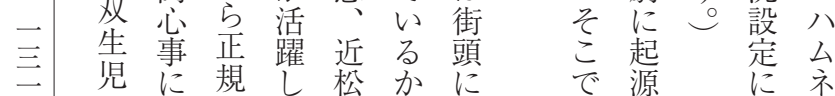

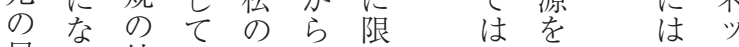

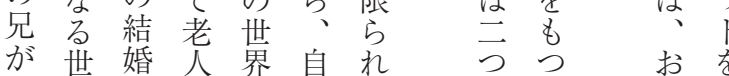
折世界蚹を界自杂 上で可欺よ民い兼、占一

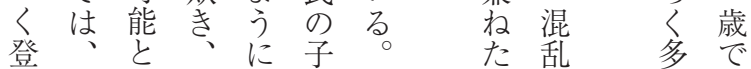
登変い若金女一学劇憇多で

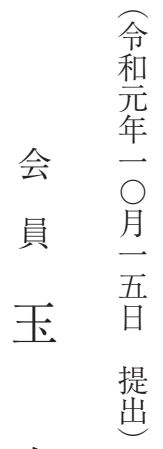

泉<smiles>[AlH2]</smiles>

州

男 


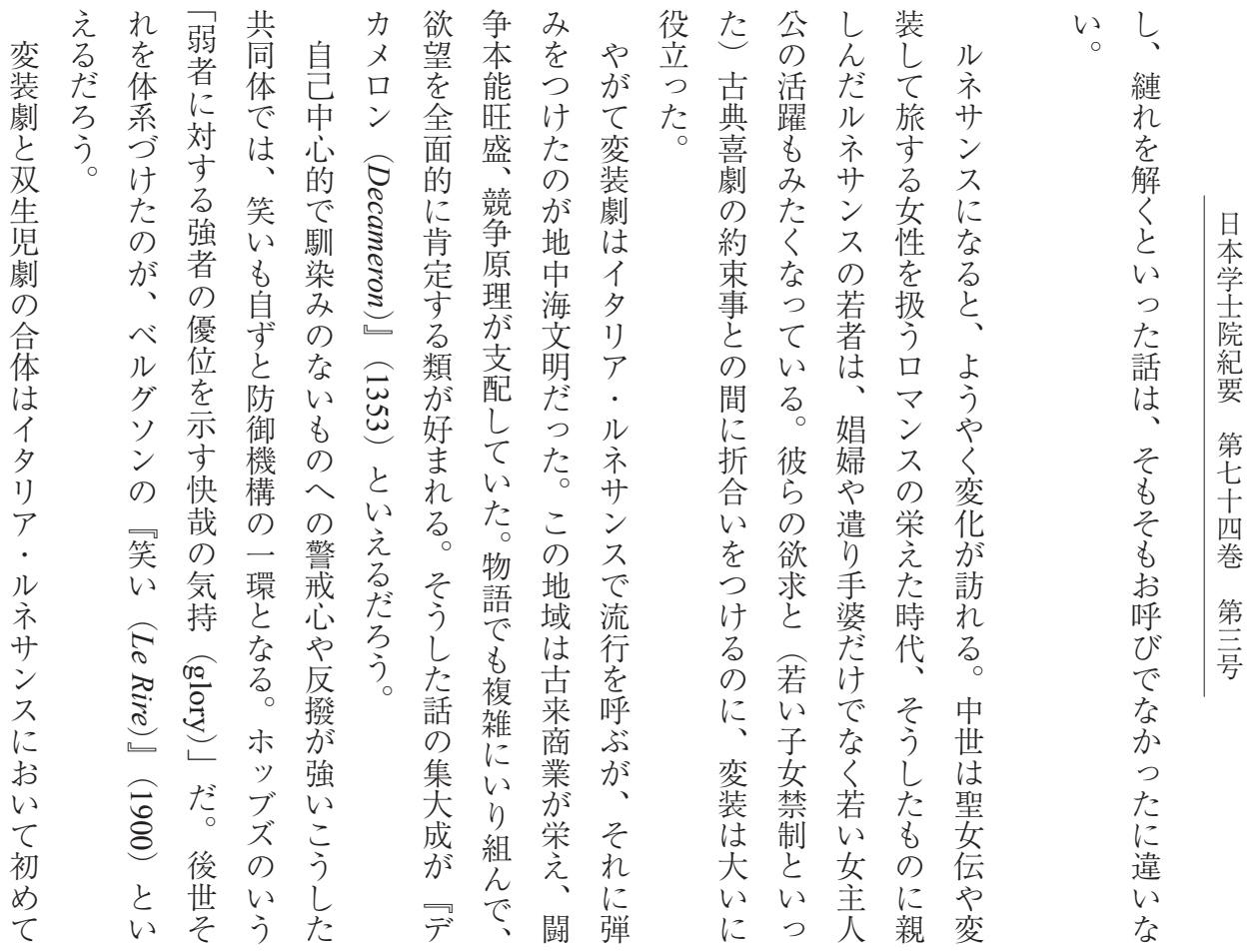

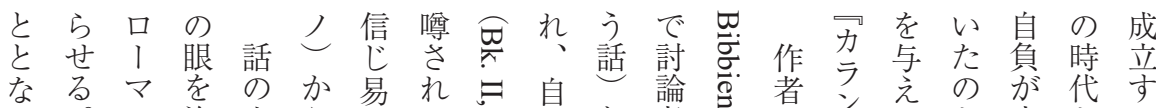

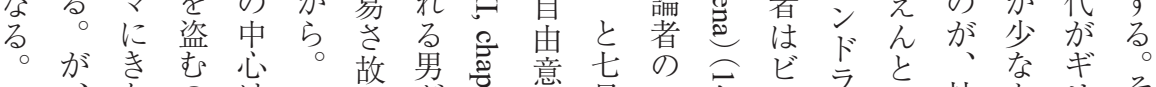

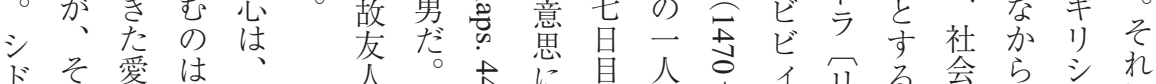

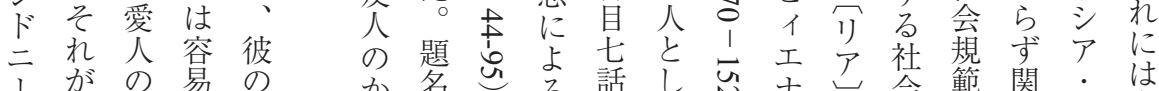

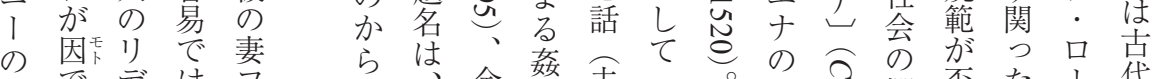

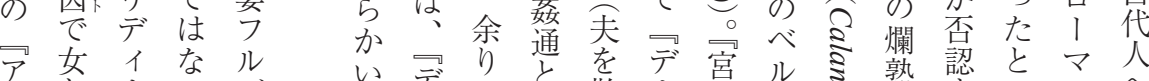

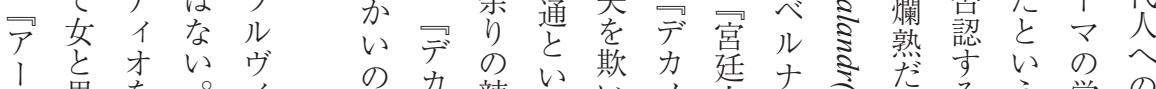

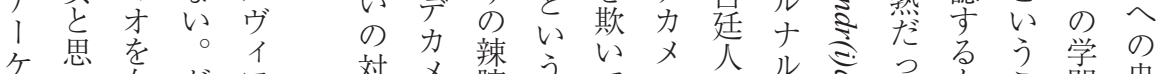

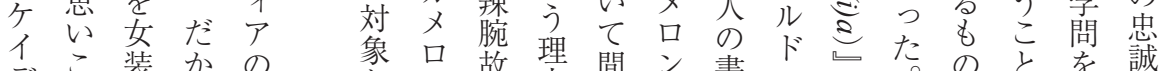

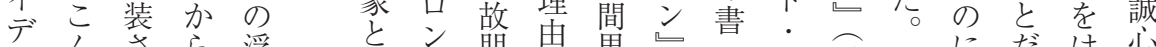

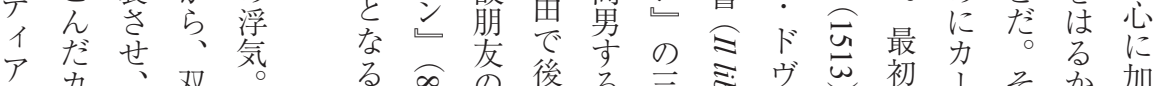

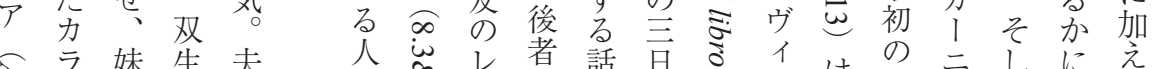

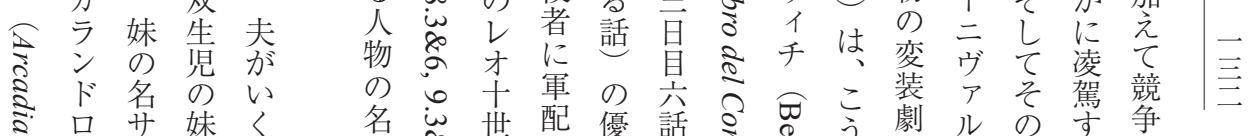

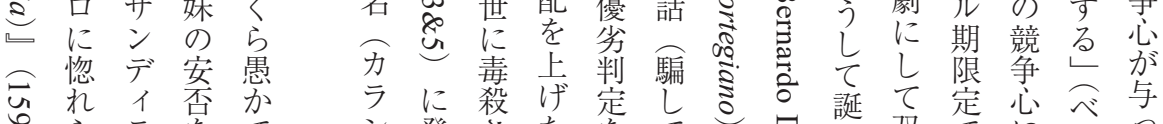

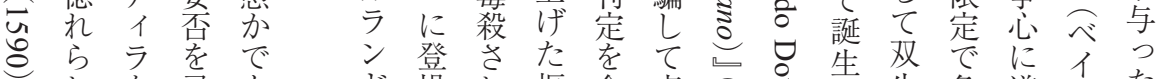

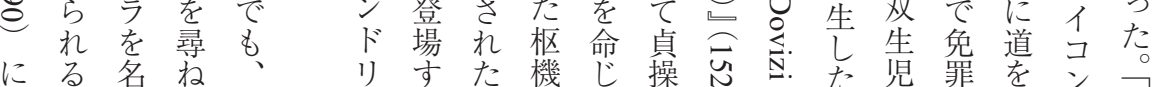

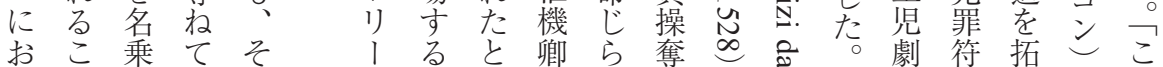




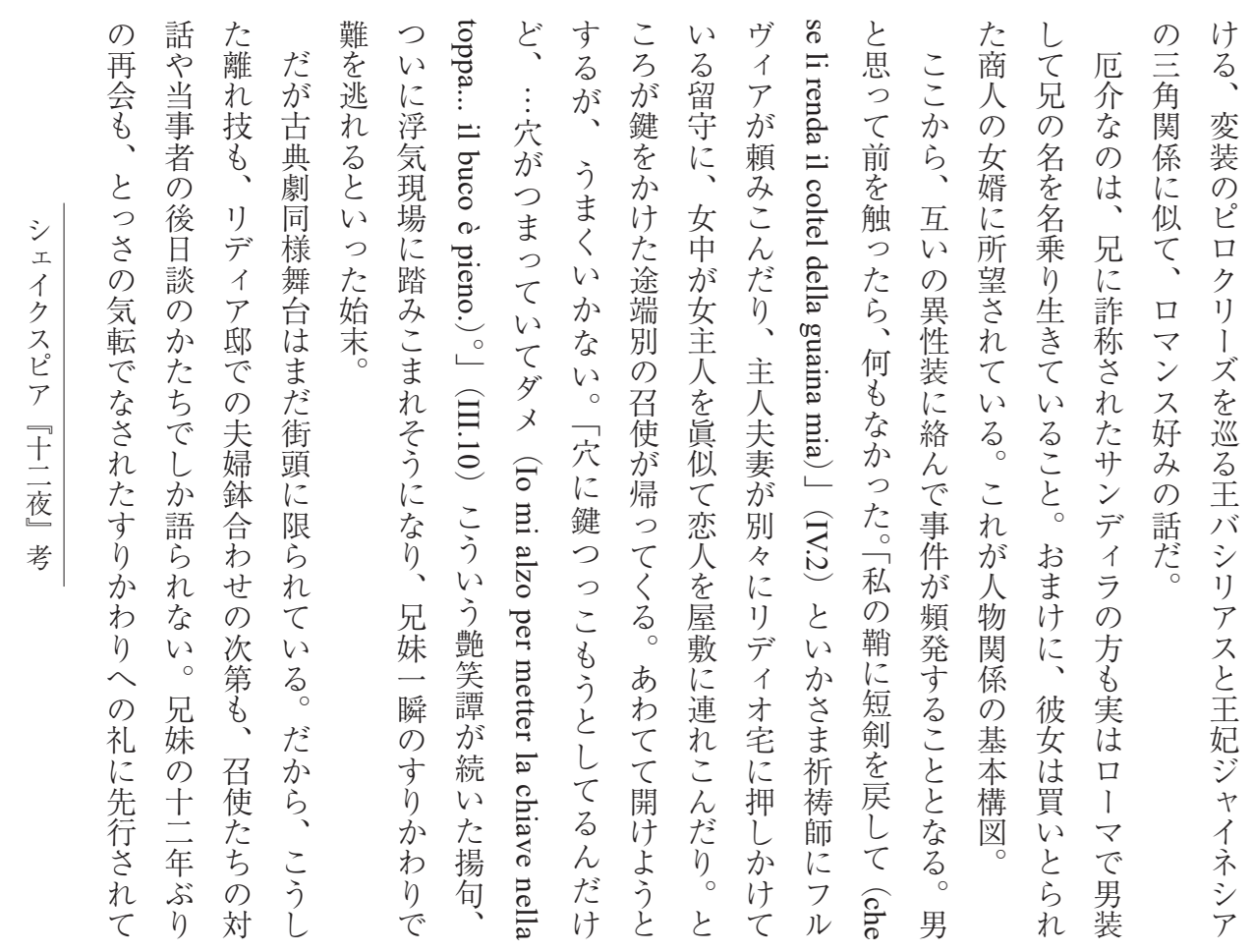

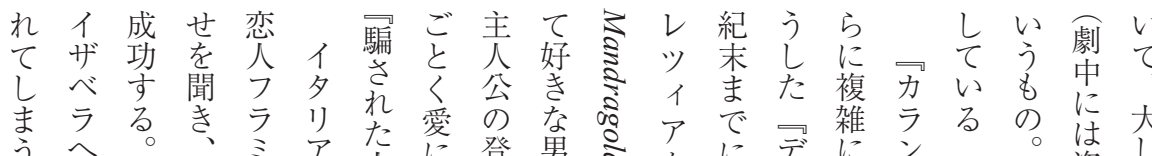

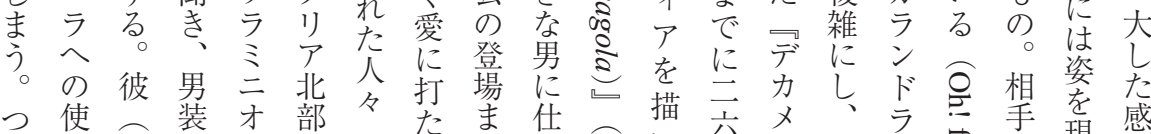

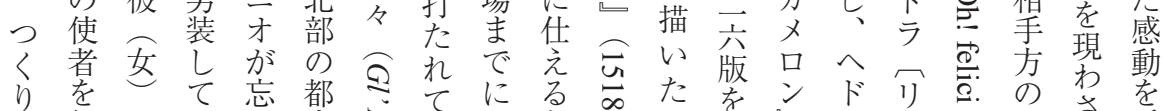

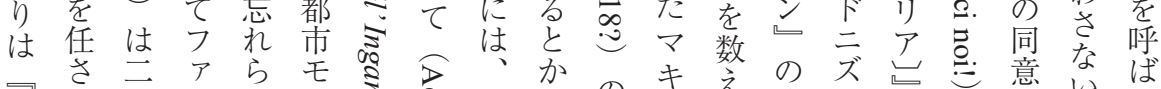

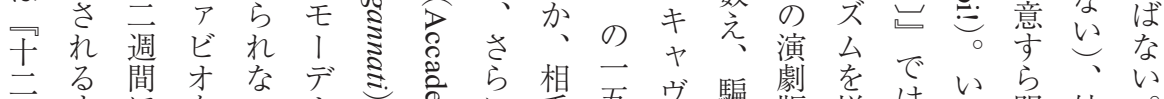

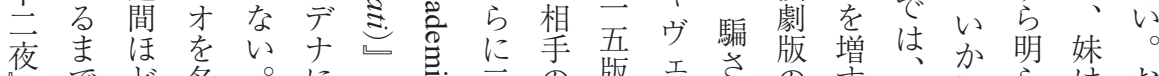

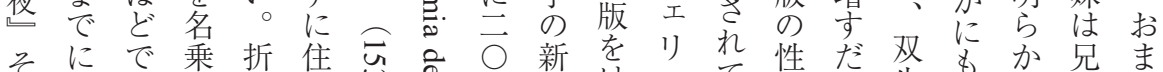
そな信りり志岕高年し新はので格性御でのけ くる用、し資さ无、心る。傑性㤎の児都な情に

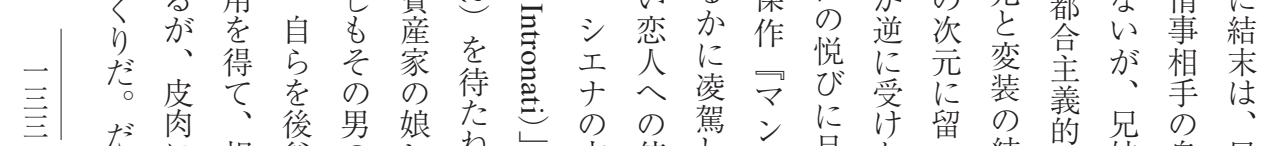

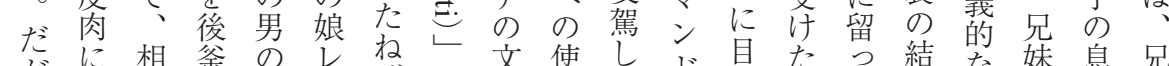

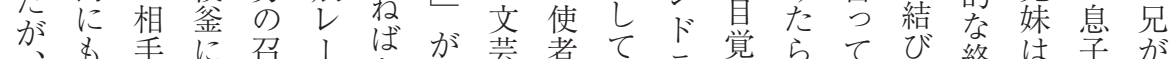

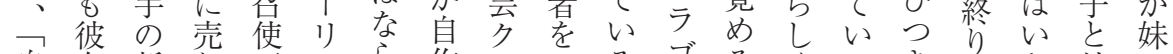
自女新り死アら作ラらるゴるくるき方た結の

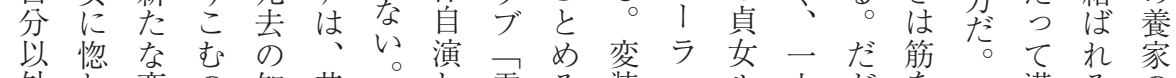

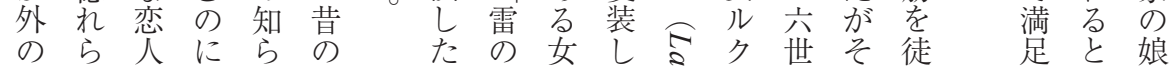




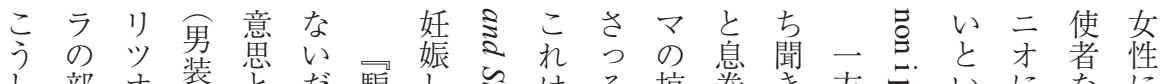

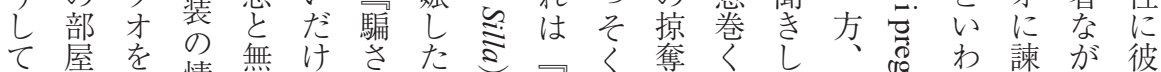

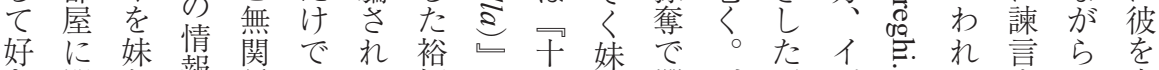

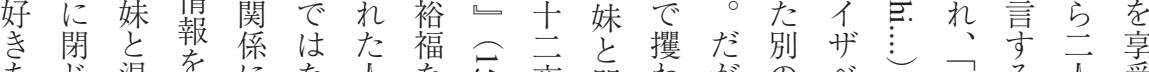
あじ混をにな人な岕夜間わがのべこ实る人受

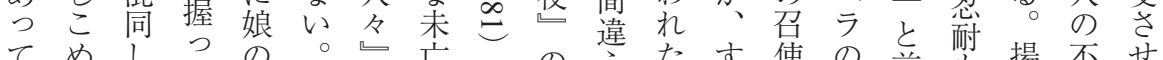
てめたててでの

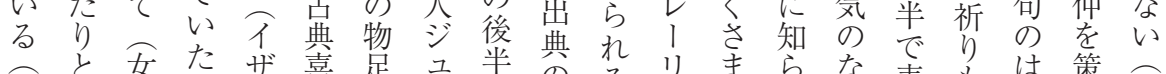

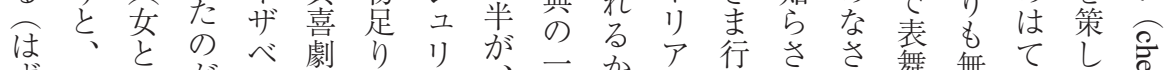

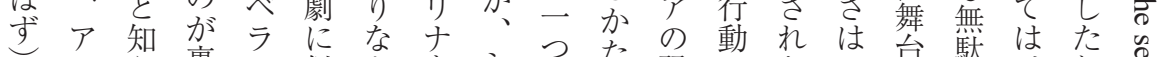

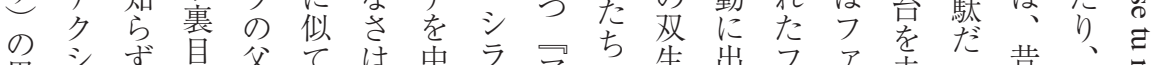

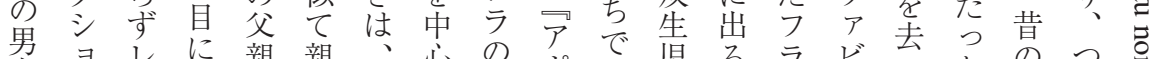

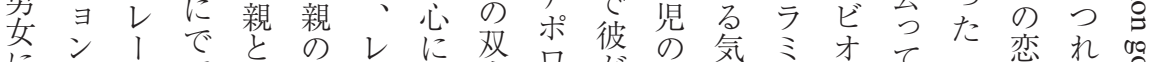

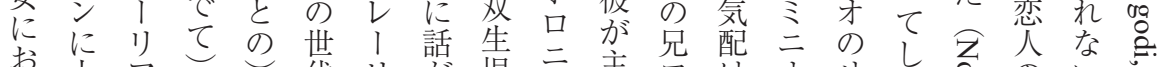

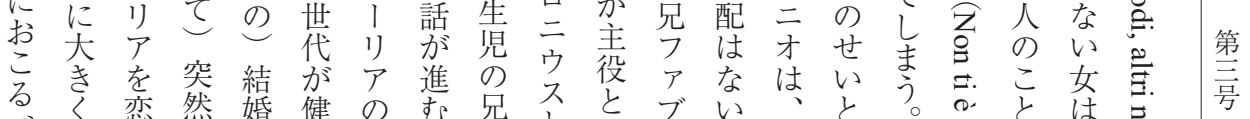

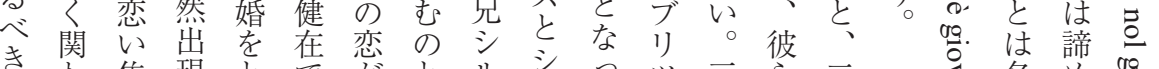

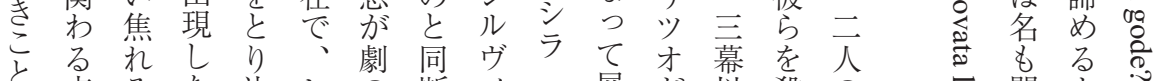

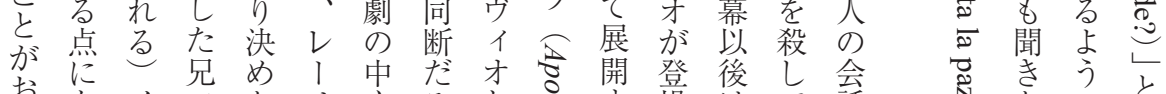

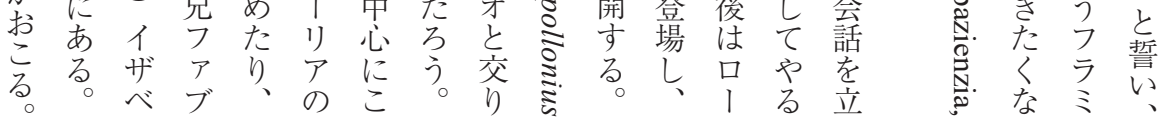

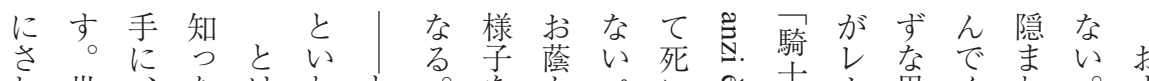

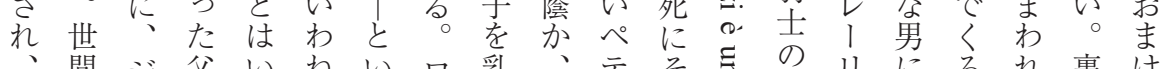

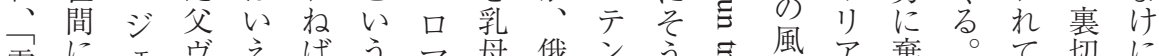

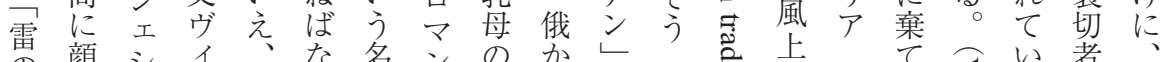
ご顔ジル 新な名ざ

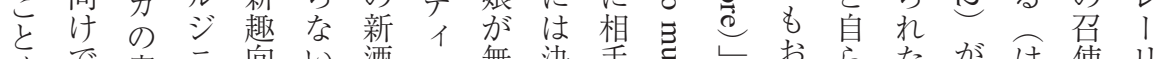

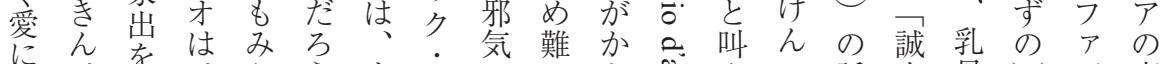

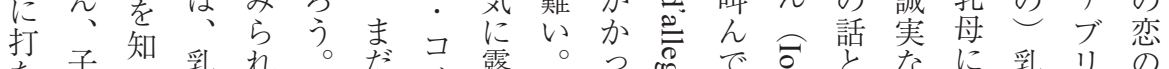

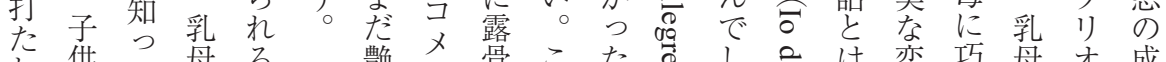

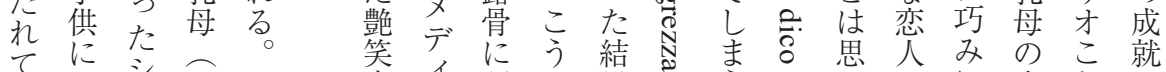

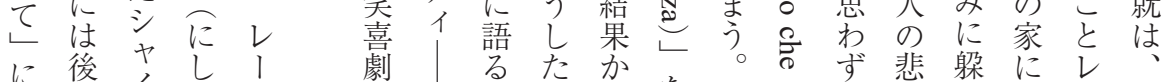

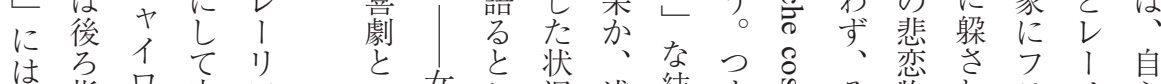

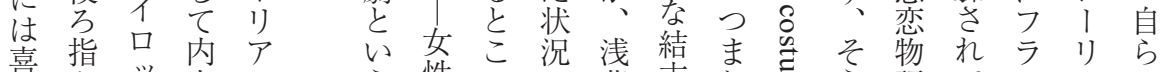

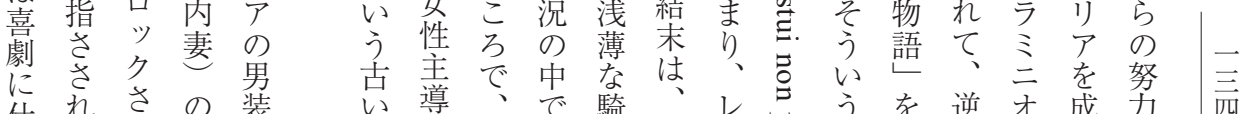

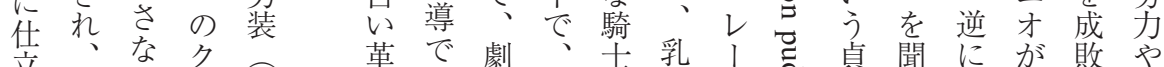

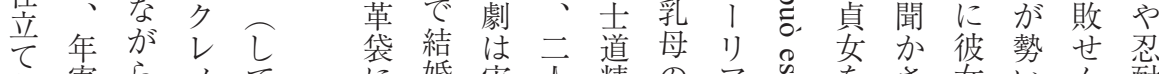

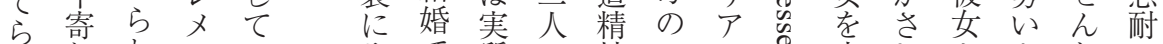

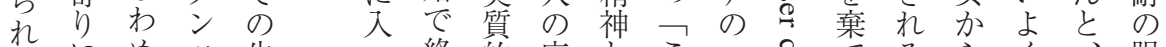

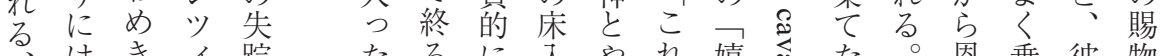

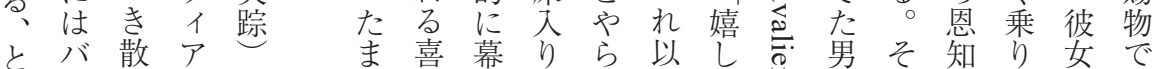

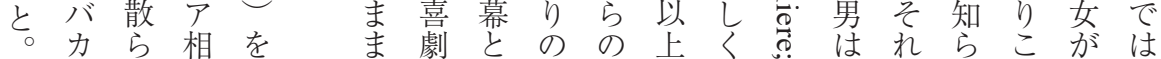



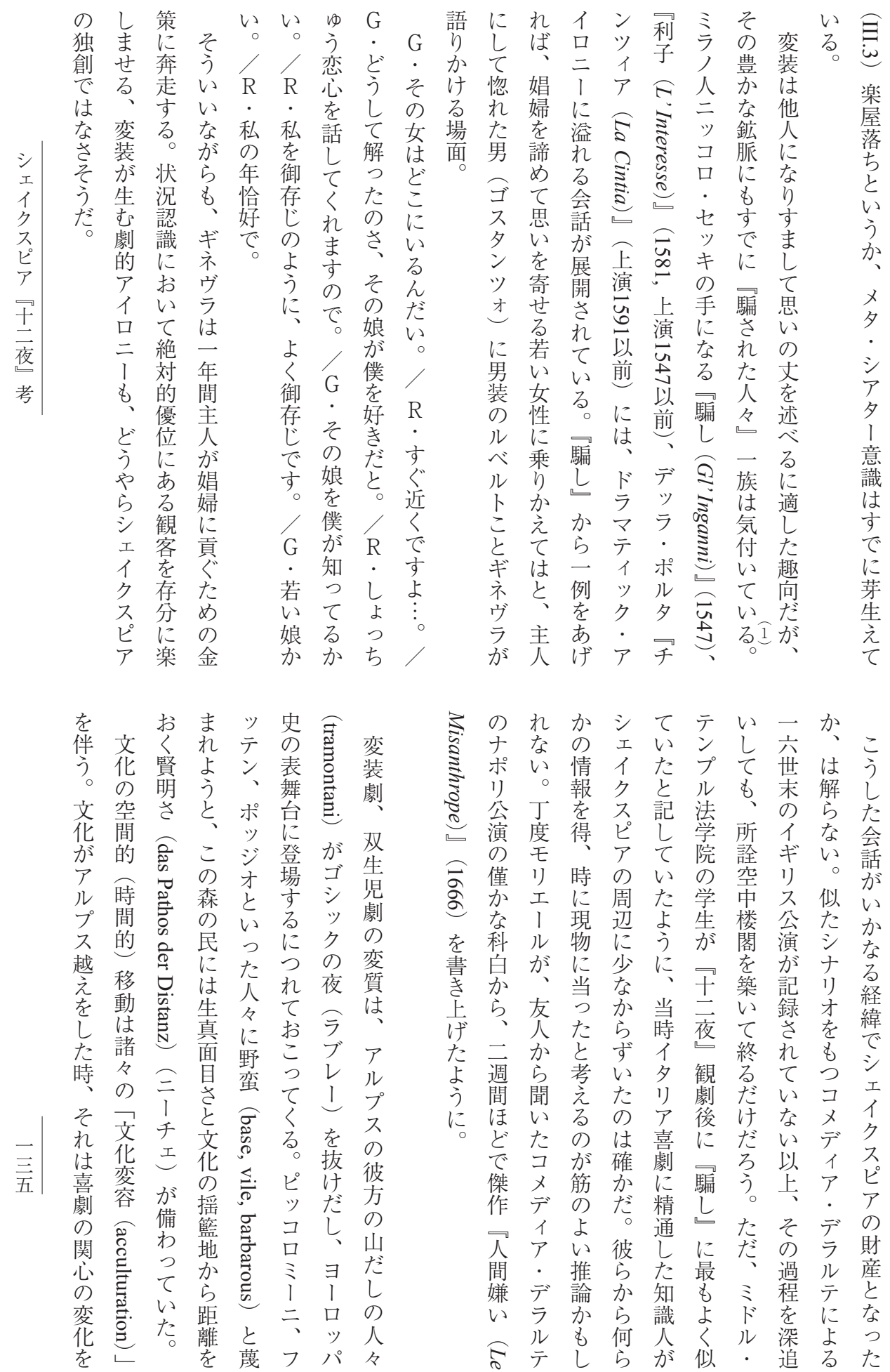


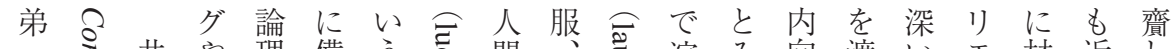

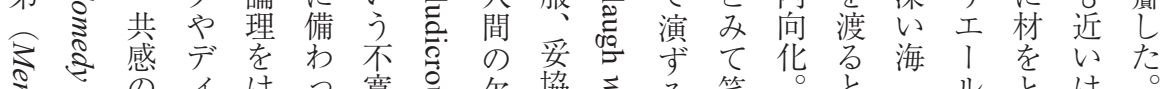
き

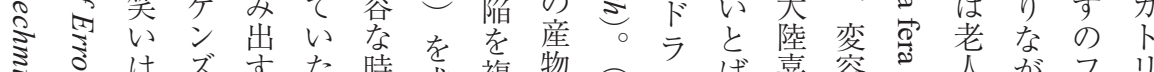

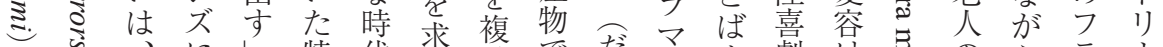

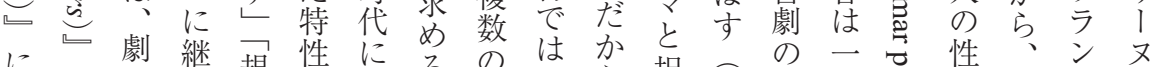

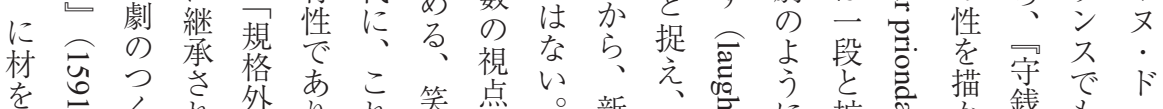

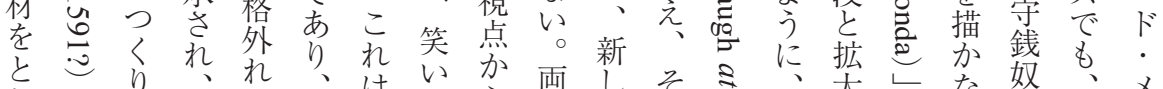

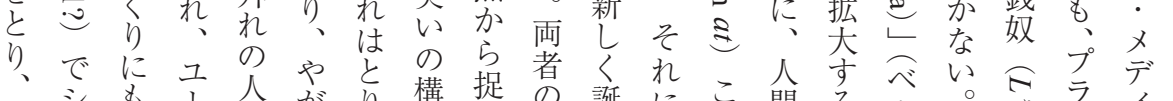
双

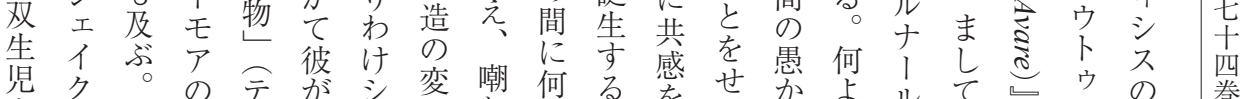

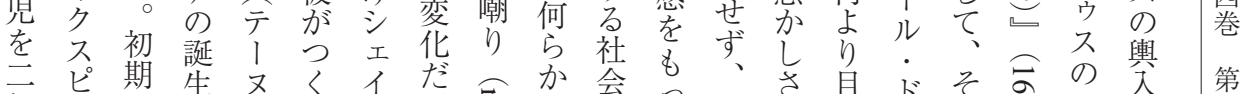

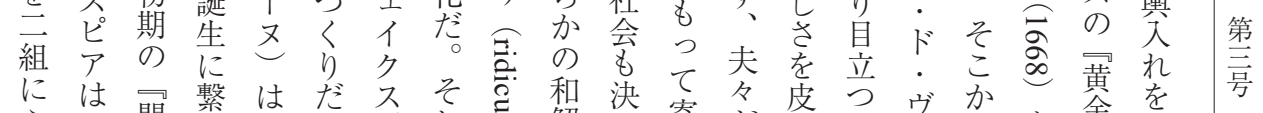

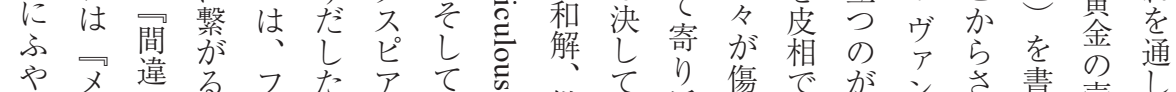
やメ違 る

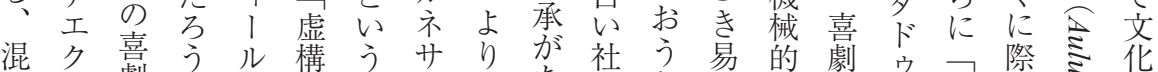

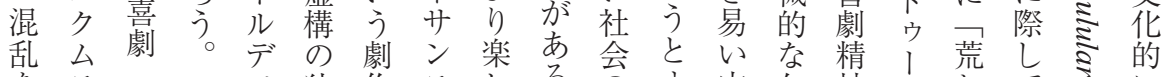

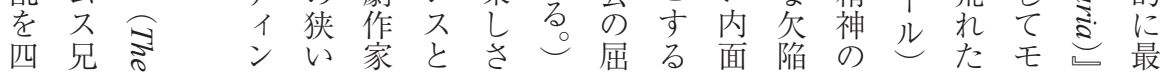

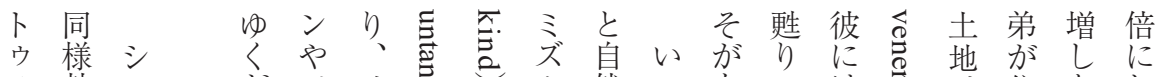

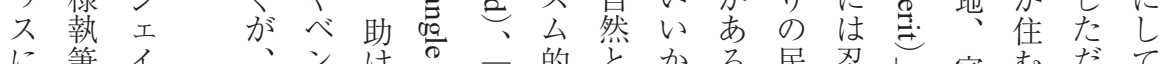

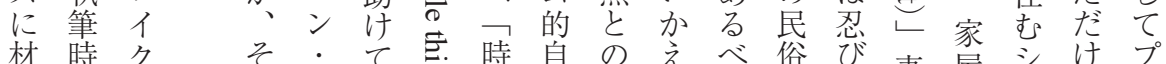

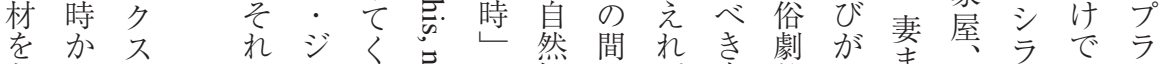

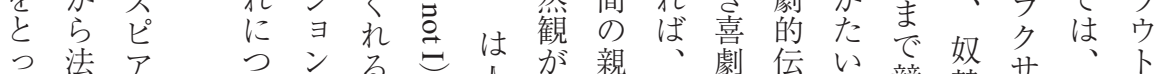

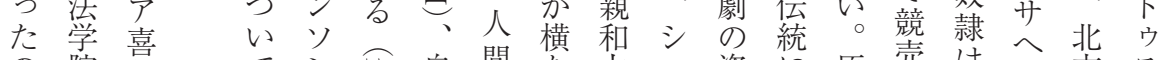
の院劇てン君自間た力エ姿に原に売は兄方 はでのに丽界わをイを包作に抏を人に

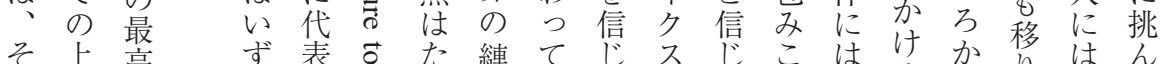

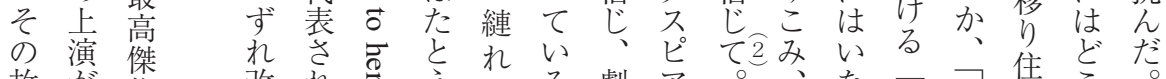

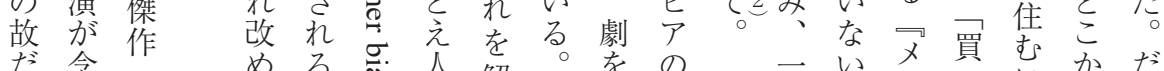

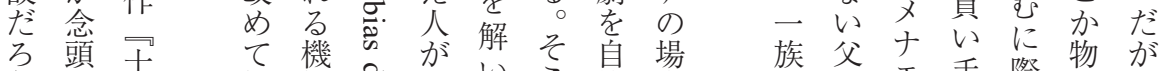

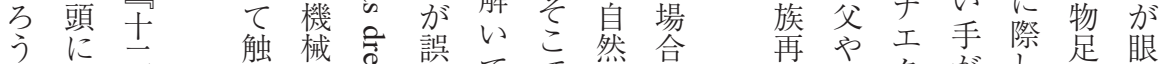

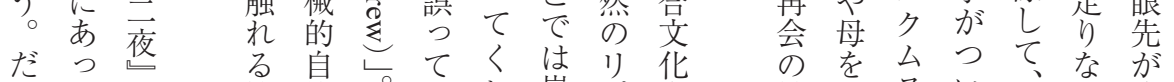

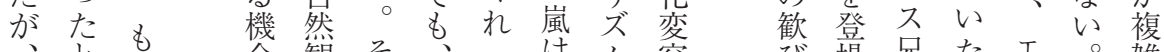

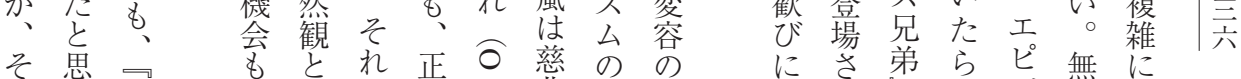

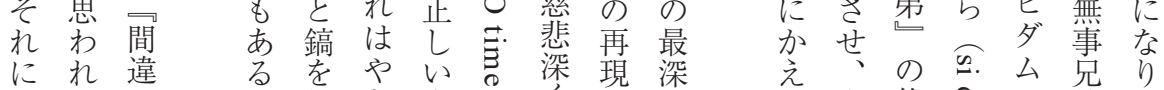
しる心削が方”くと層当全終异又弟不

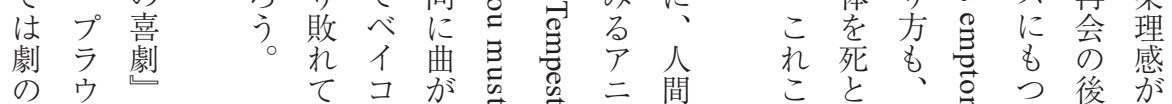




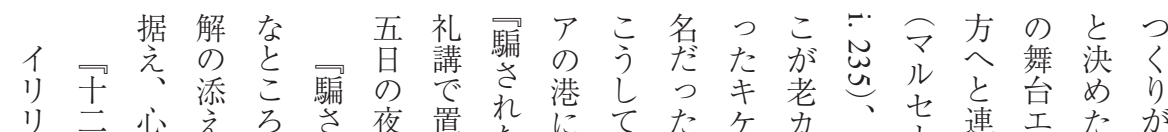

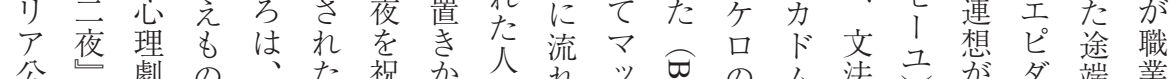

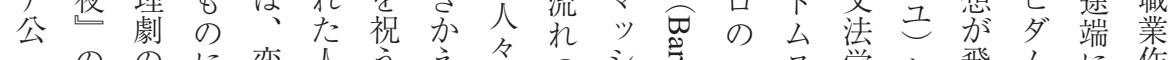

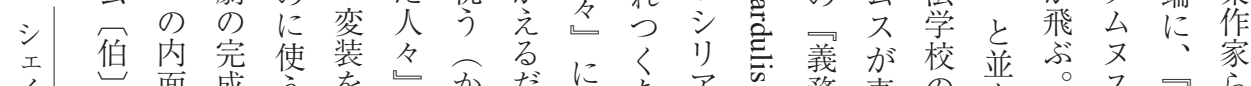

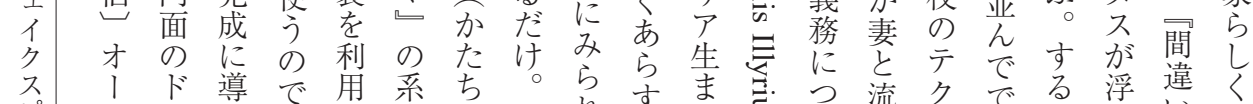

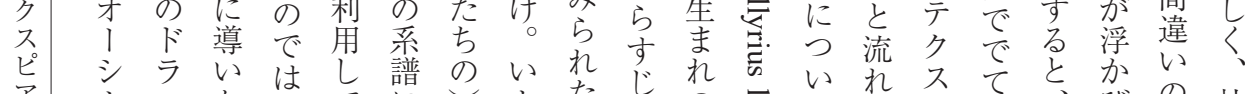

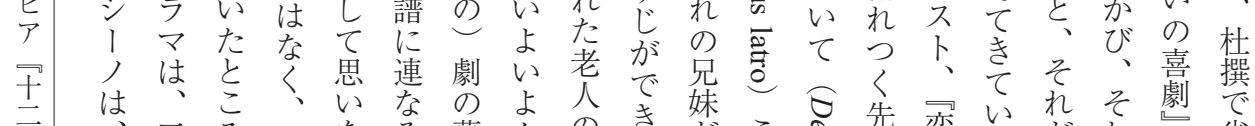

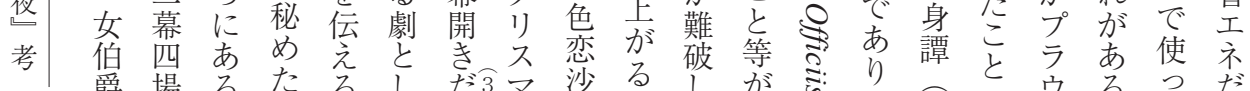

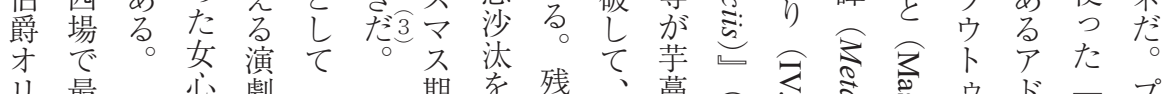

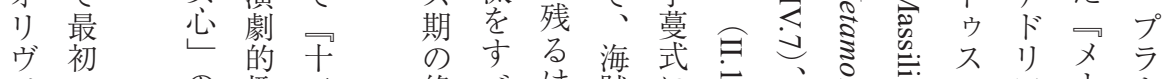

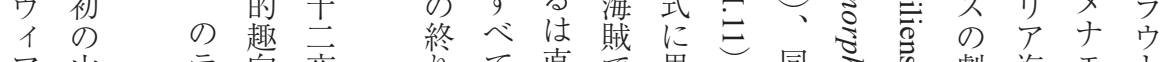

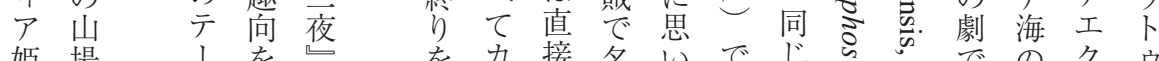

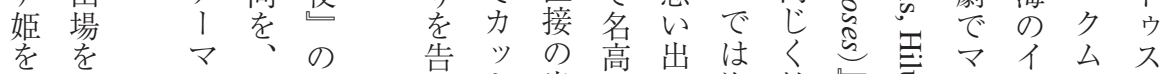

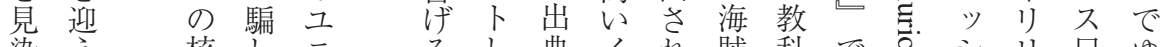

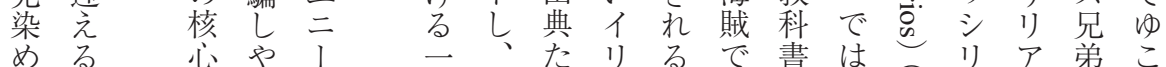

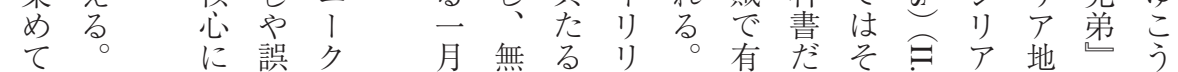

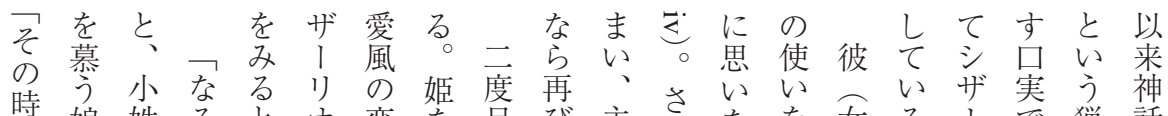
そ娘姓ると、オ恋を貝び主らをを訪るる! 幍話

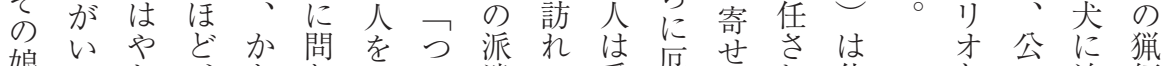

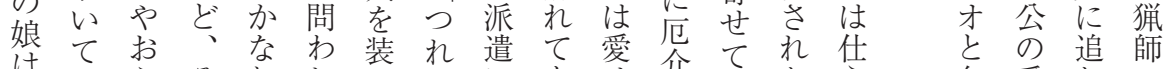

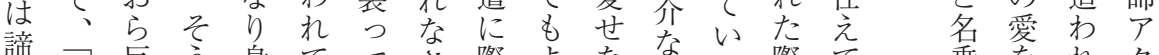

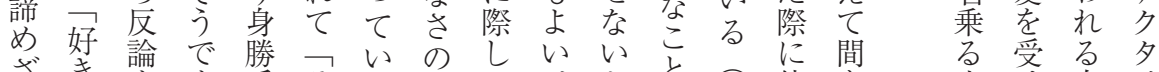

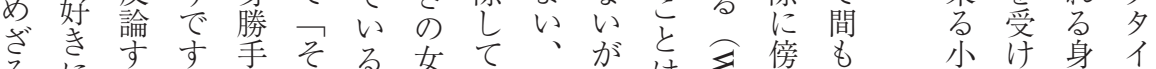

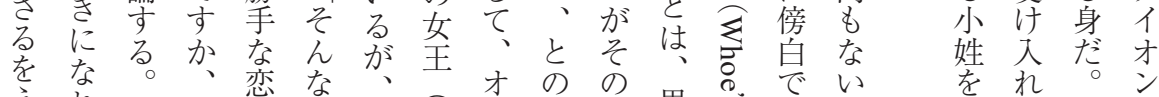

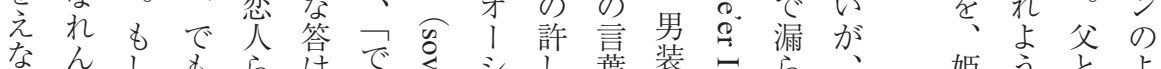

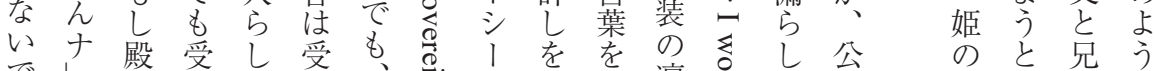

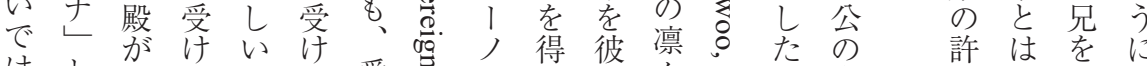

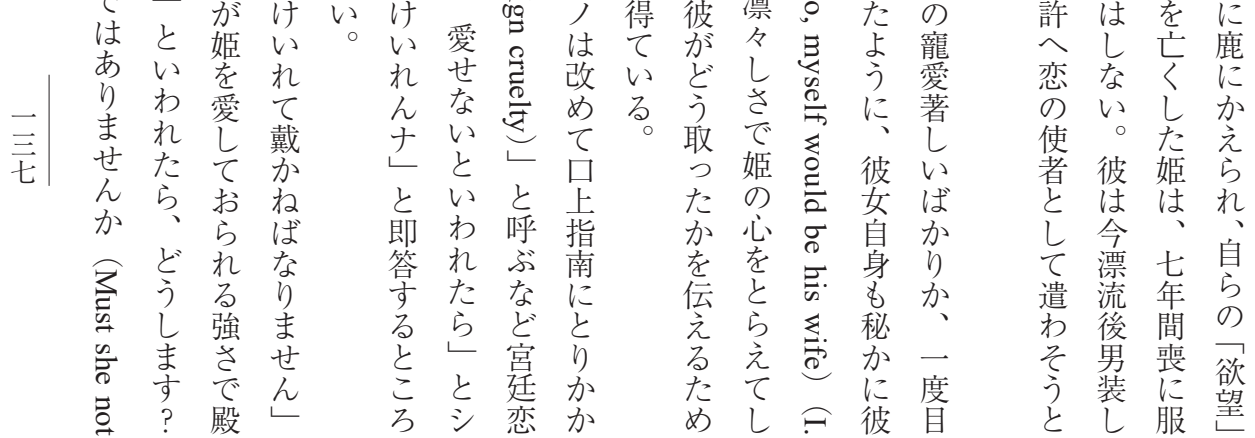



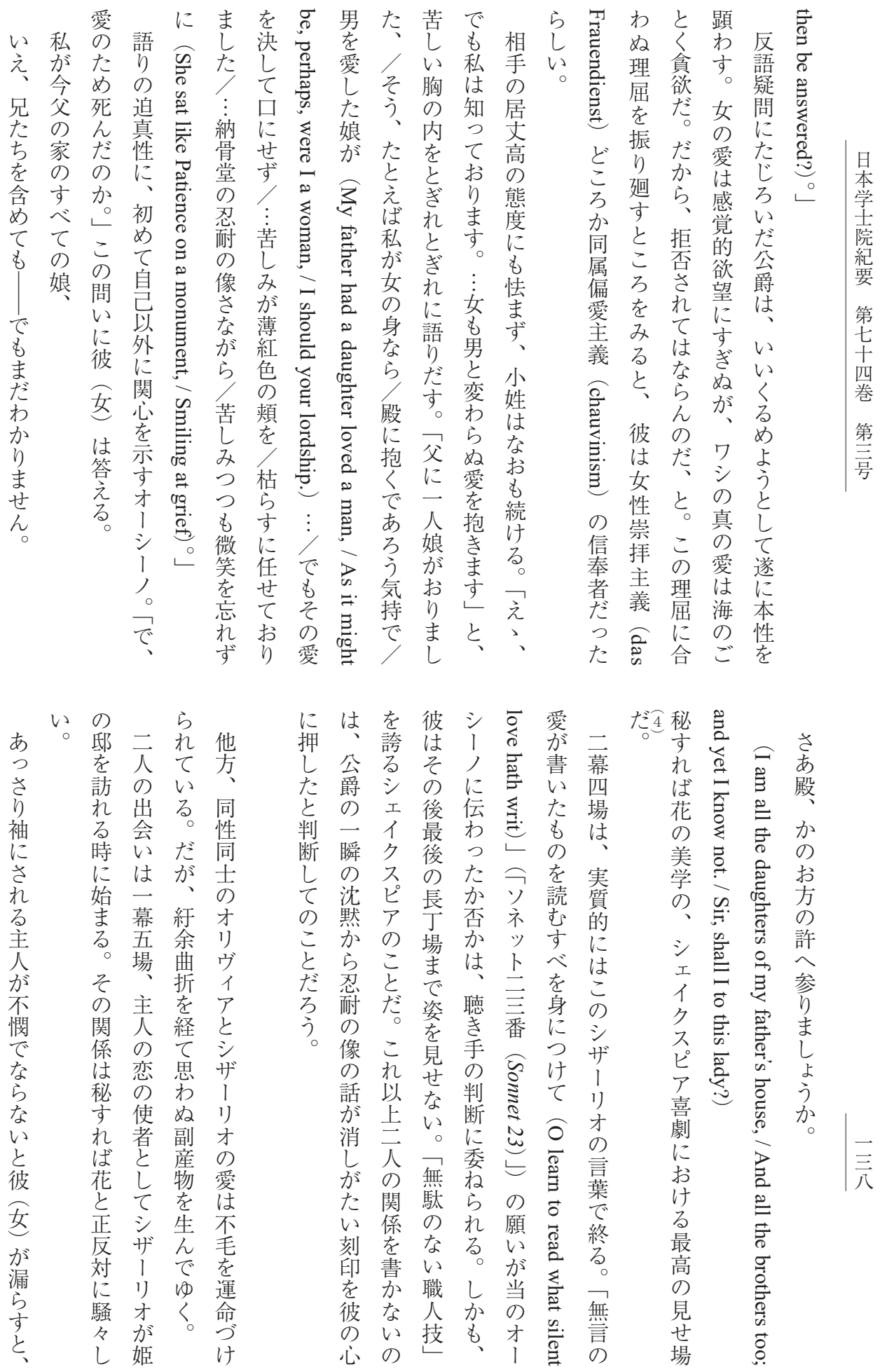


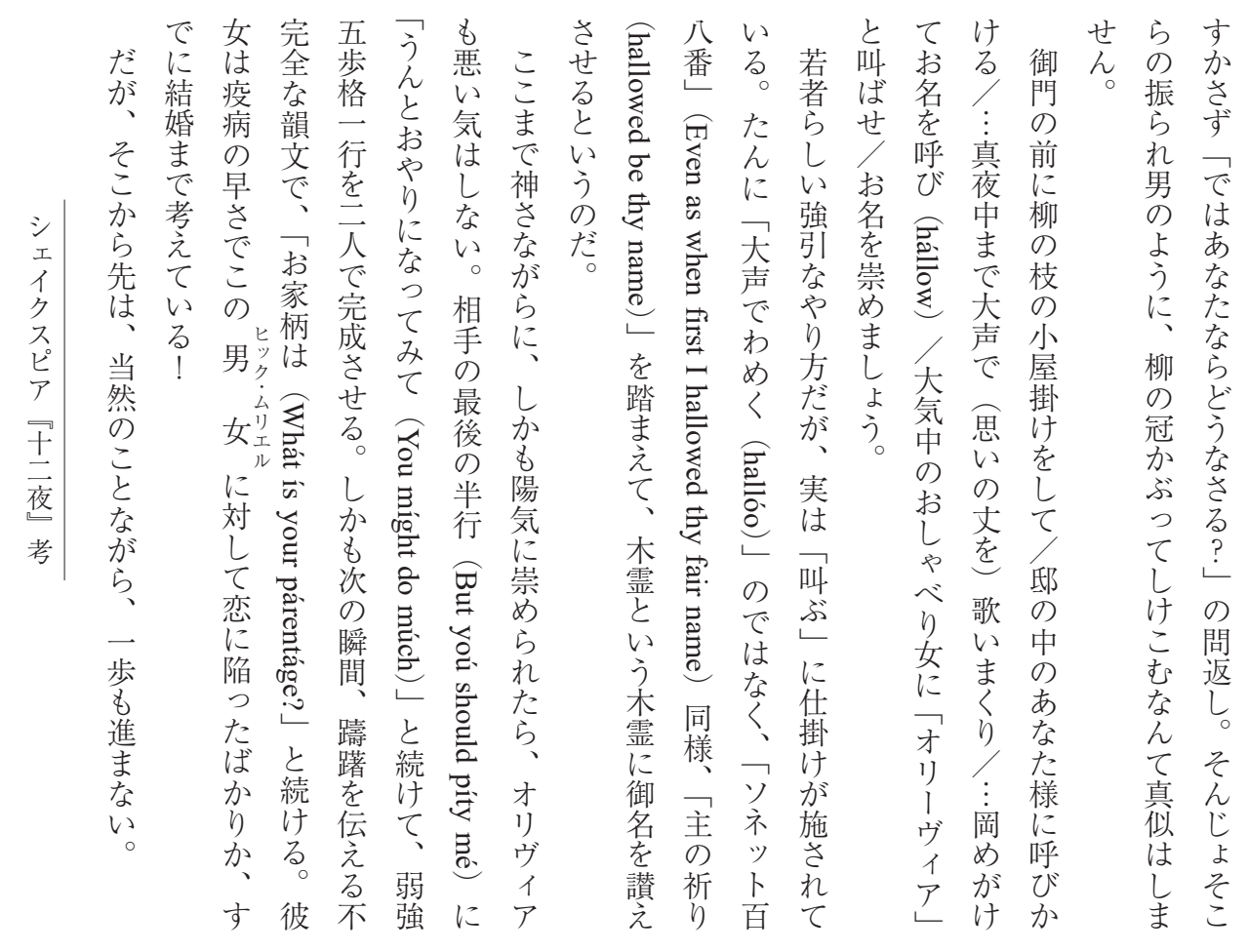

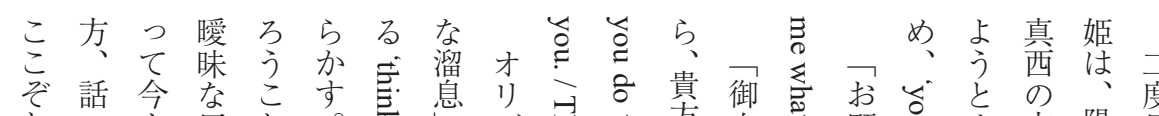

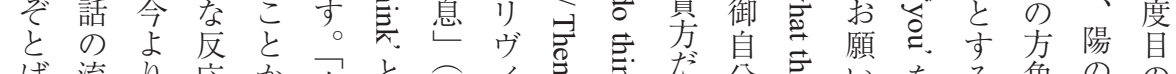

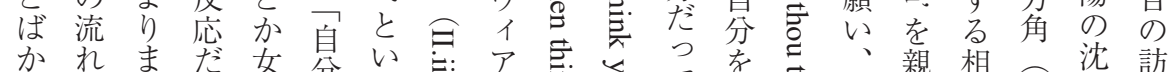

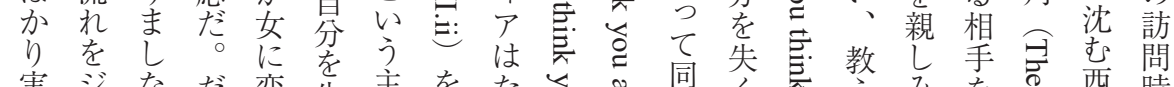

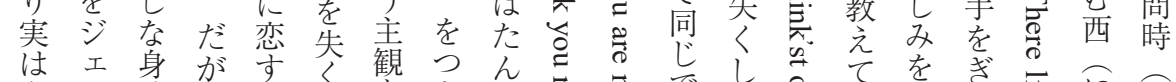

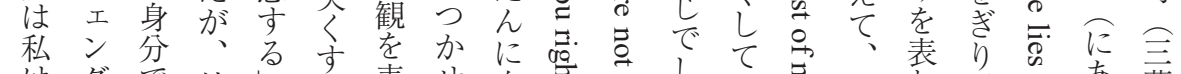

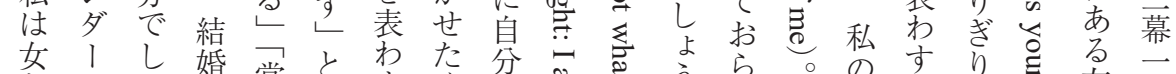

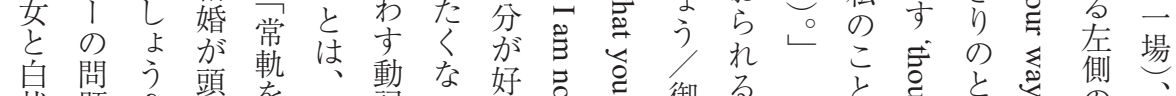

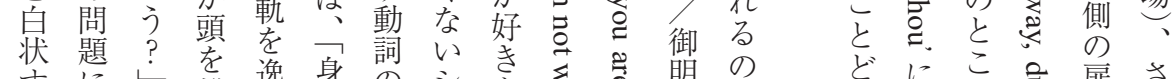

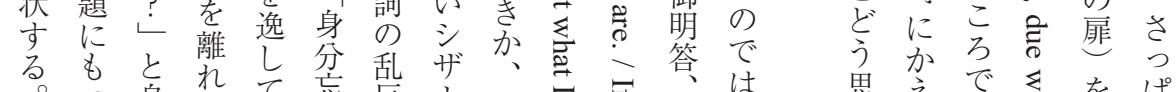

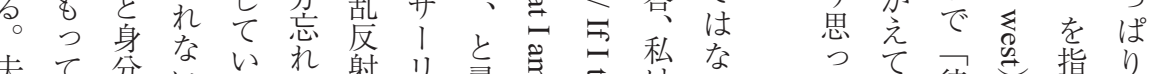

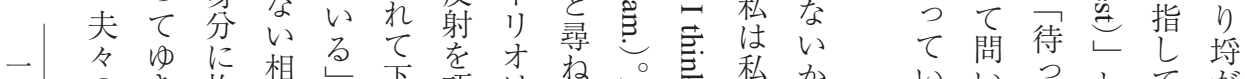

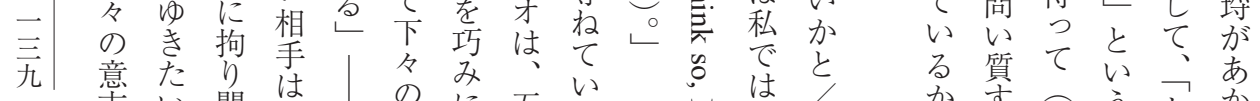

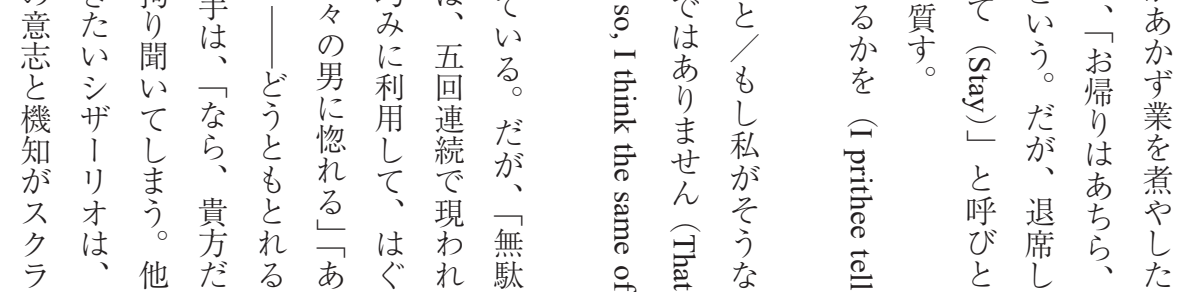




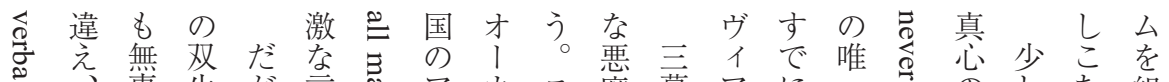

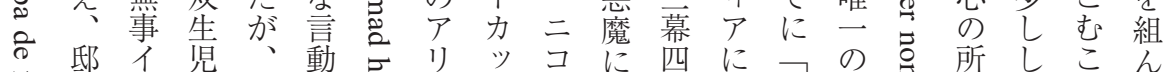

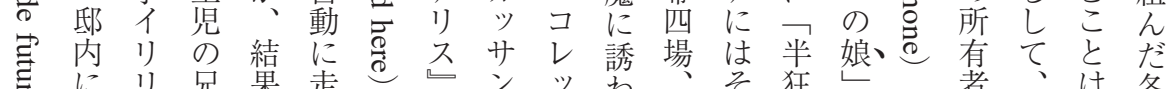

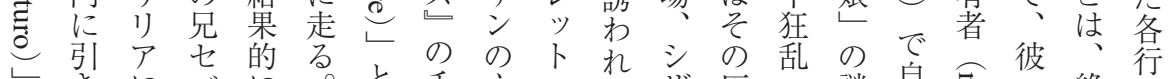

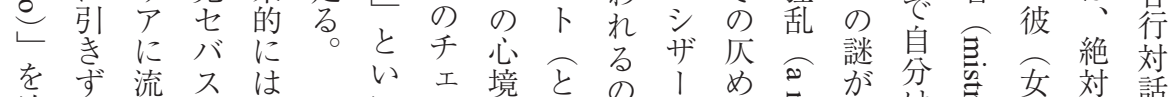

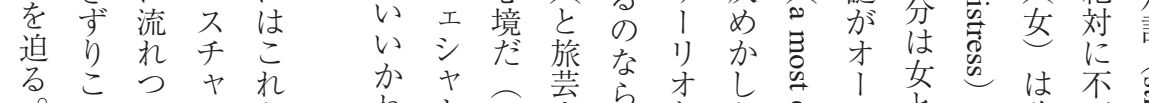

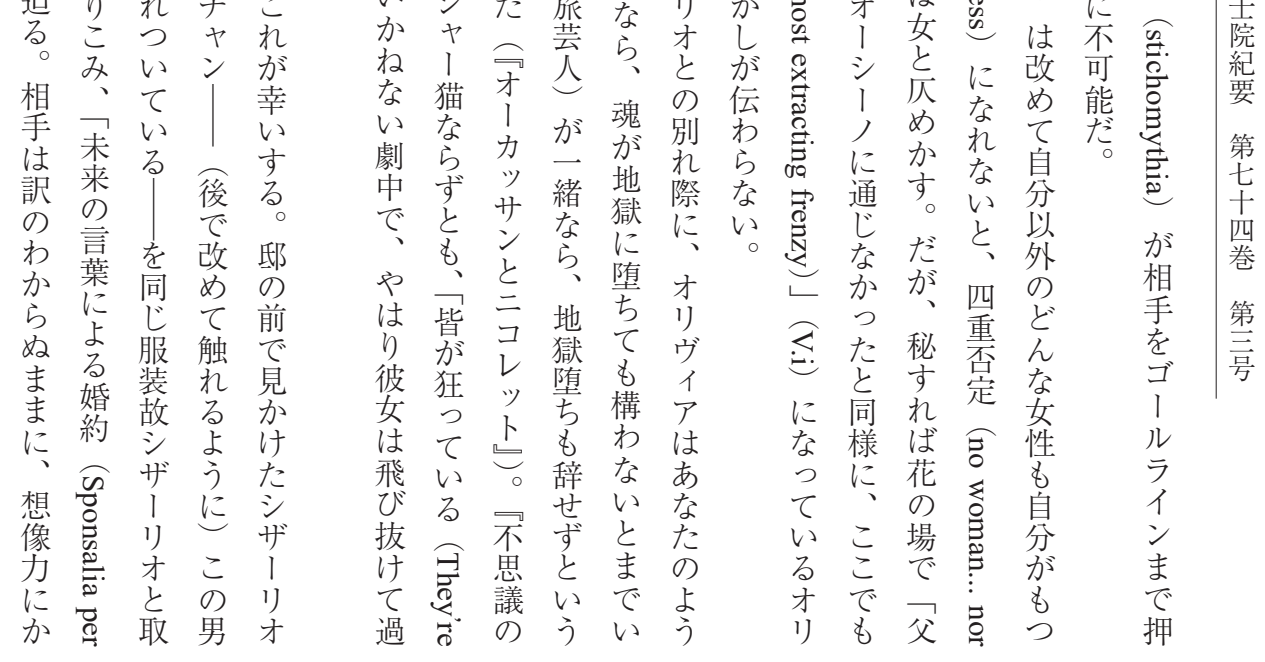

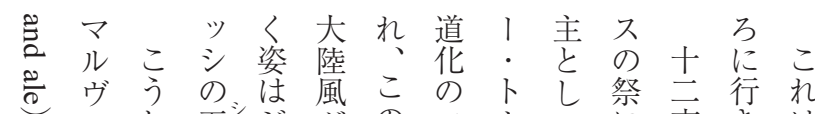

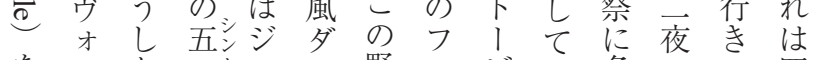

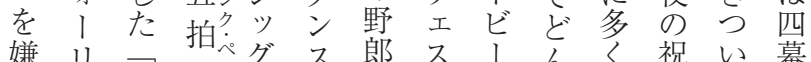

嫌リ場子文調 ス 郎

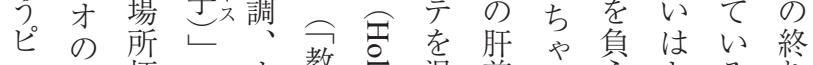

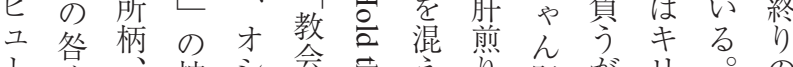

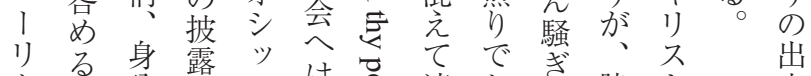

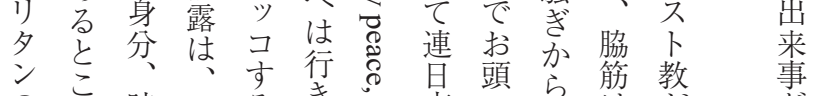

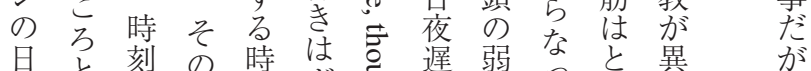

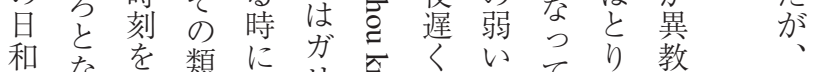

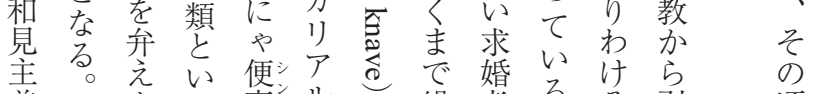

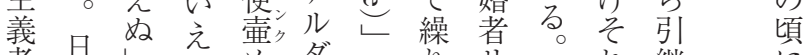

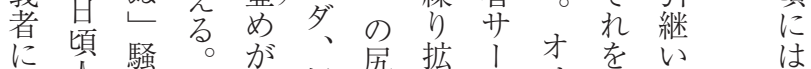

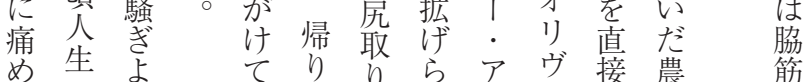

め生よ

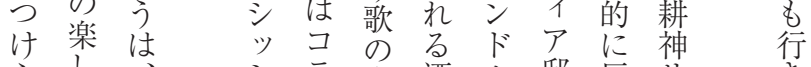

れ

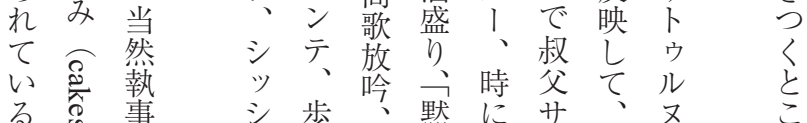

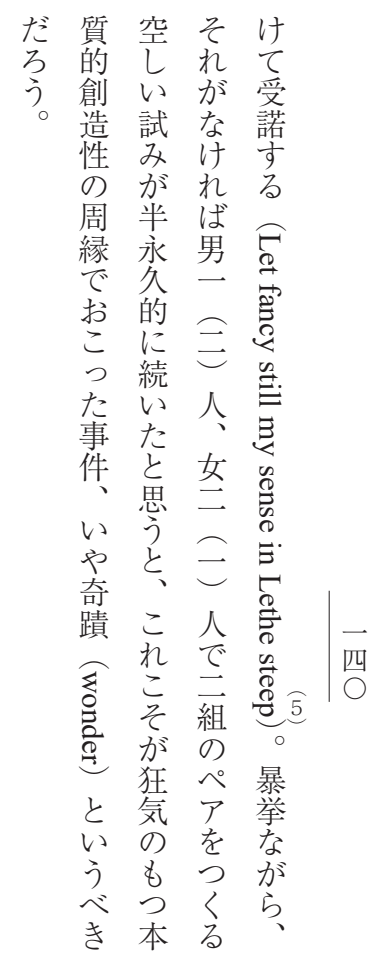




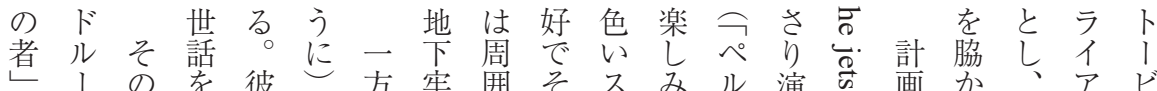

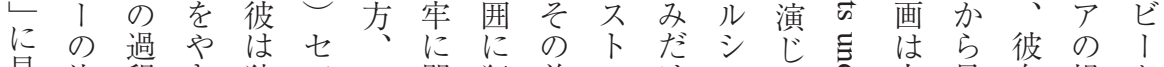

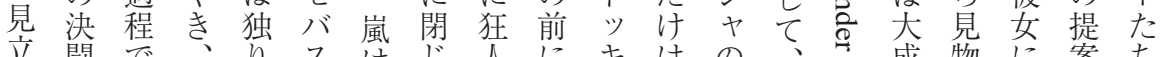

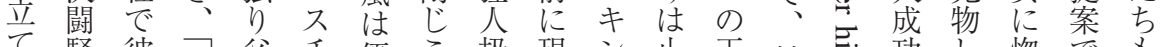

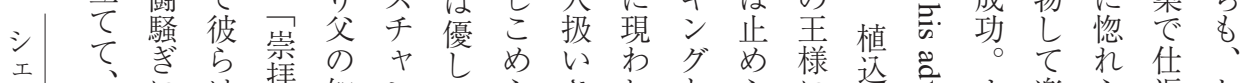

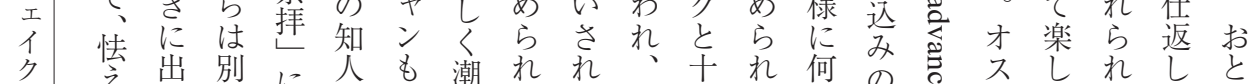

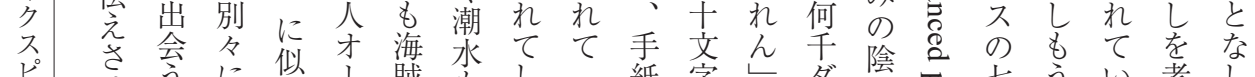

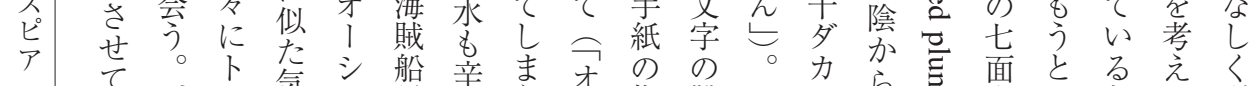
声楽だ等

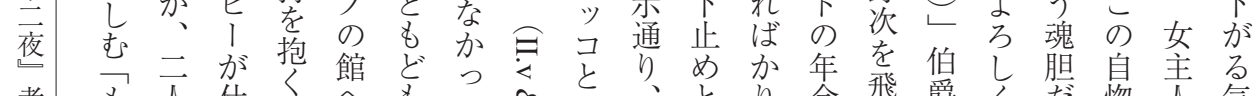

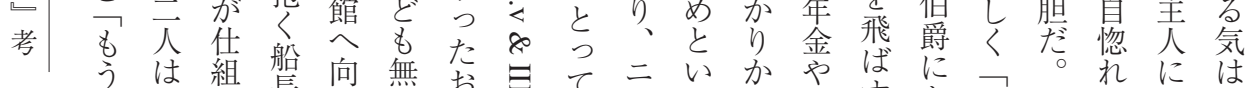

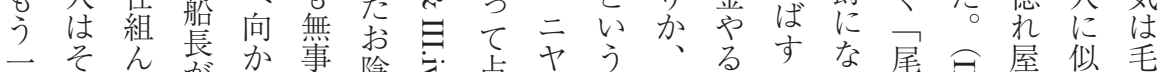

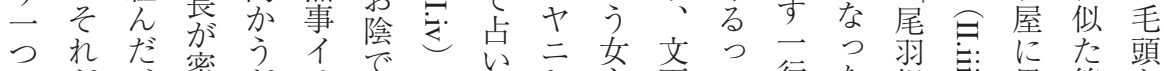
のが、密がリで㨇ヤ主面て行た根主思筆な

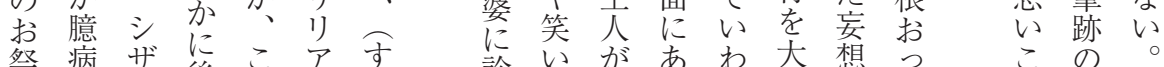

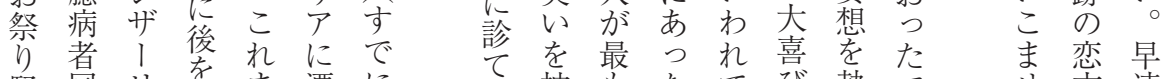

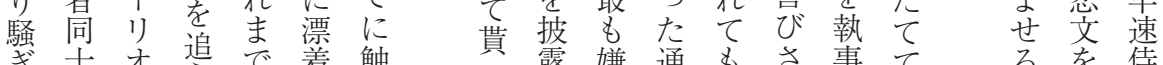

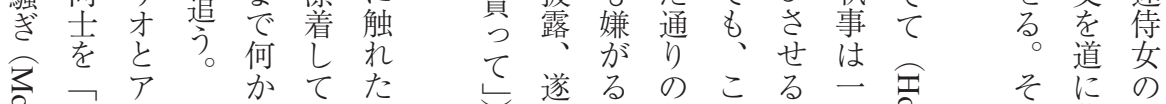

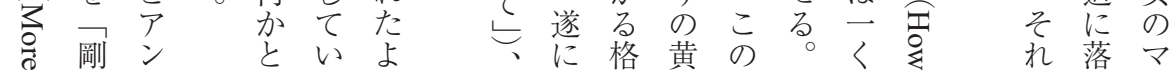

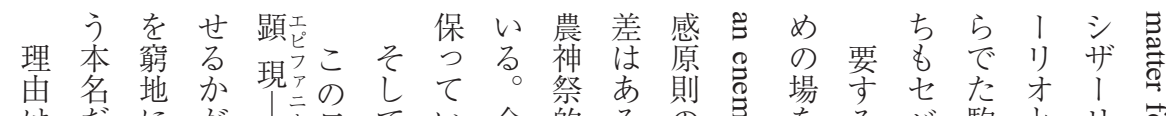

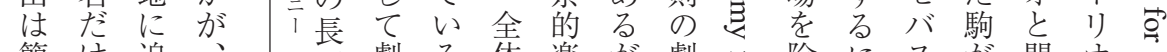
簢け追劇に丁劇る体楽が劇灾除に不が間才。

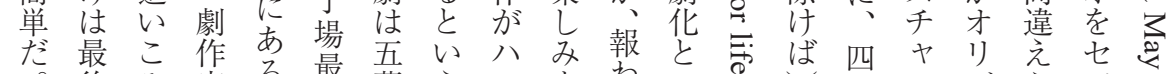

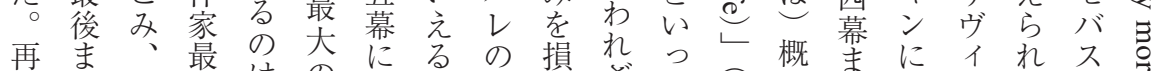

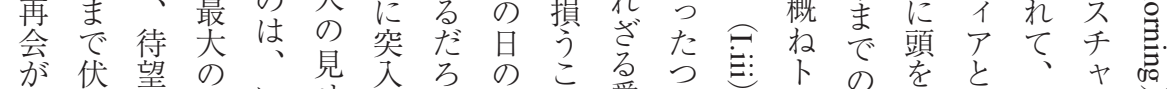

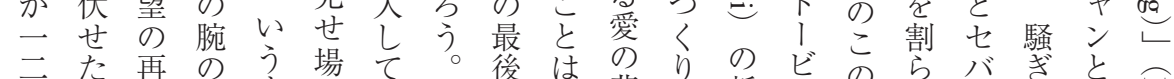

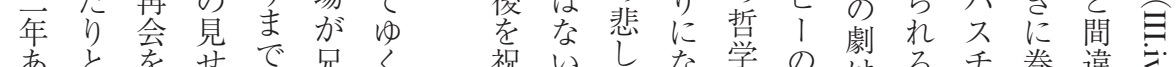

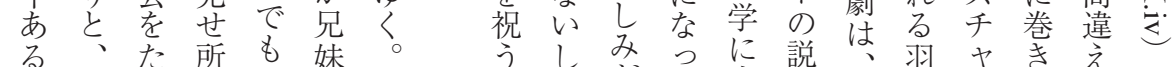
い彼えになの ははずない再

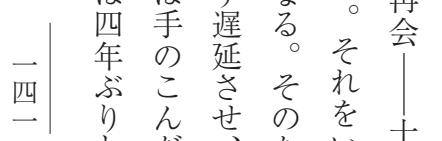

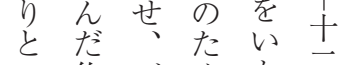
い焦管め方夜 た L 夕行 $ラ$ | 的応

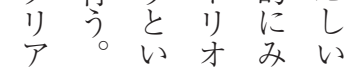

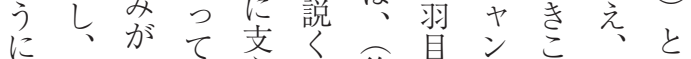

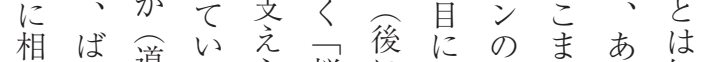
応か直るら恼にな解れる知 し騒化。机外触る逅ていら いぎ忽たごれ。なゆはな

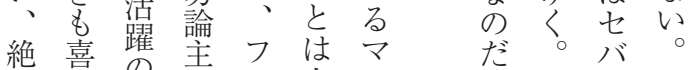

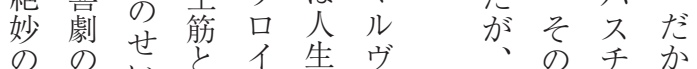

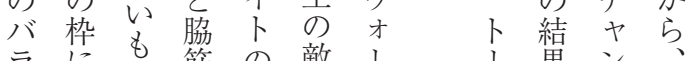

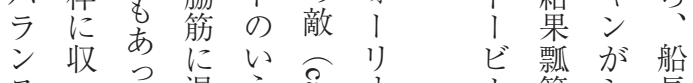

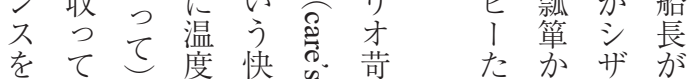



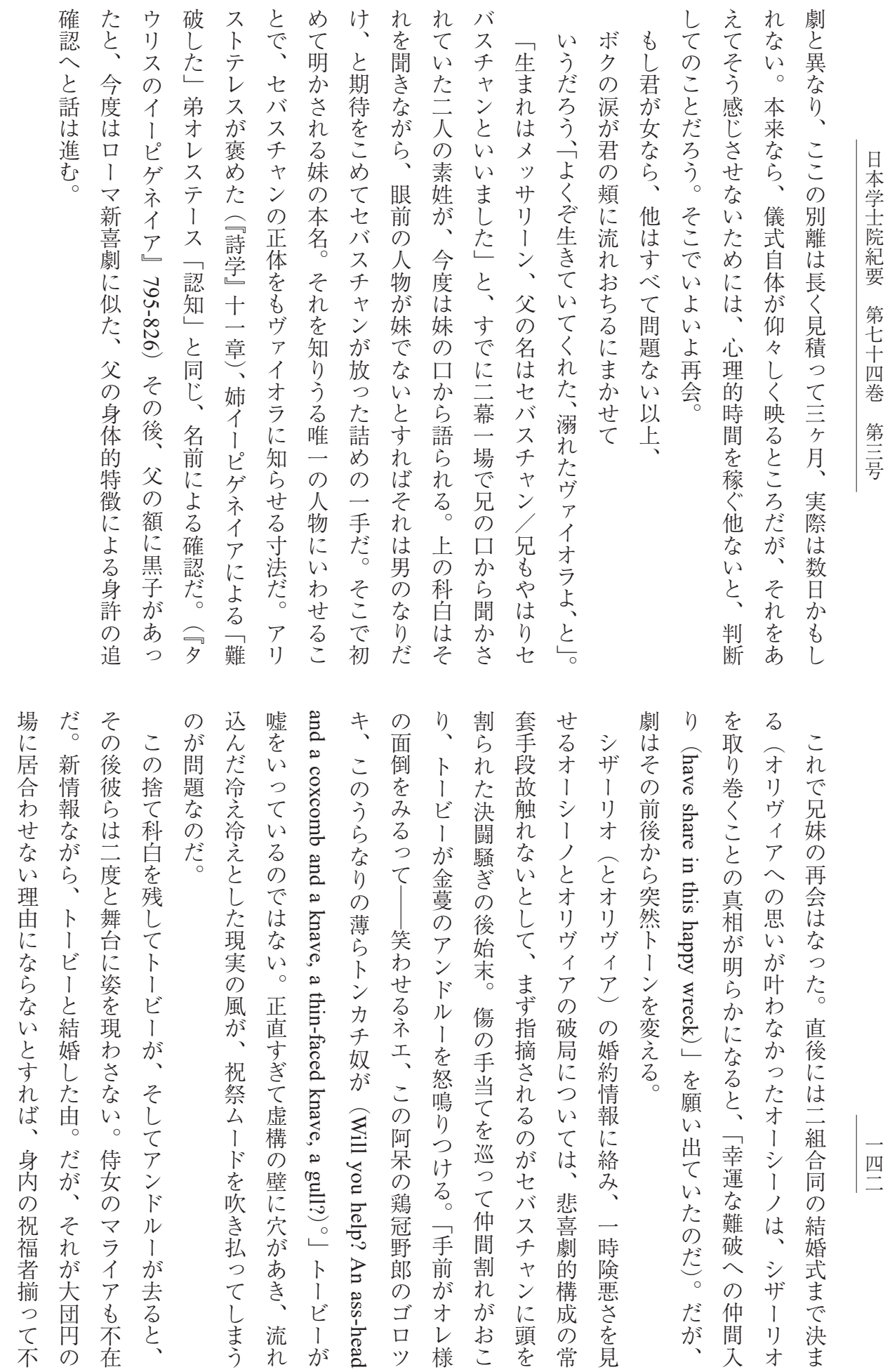


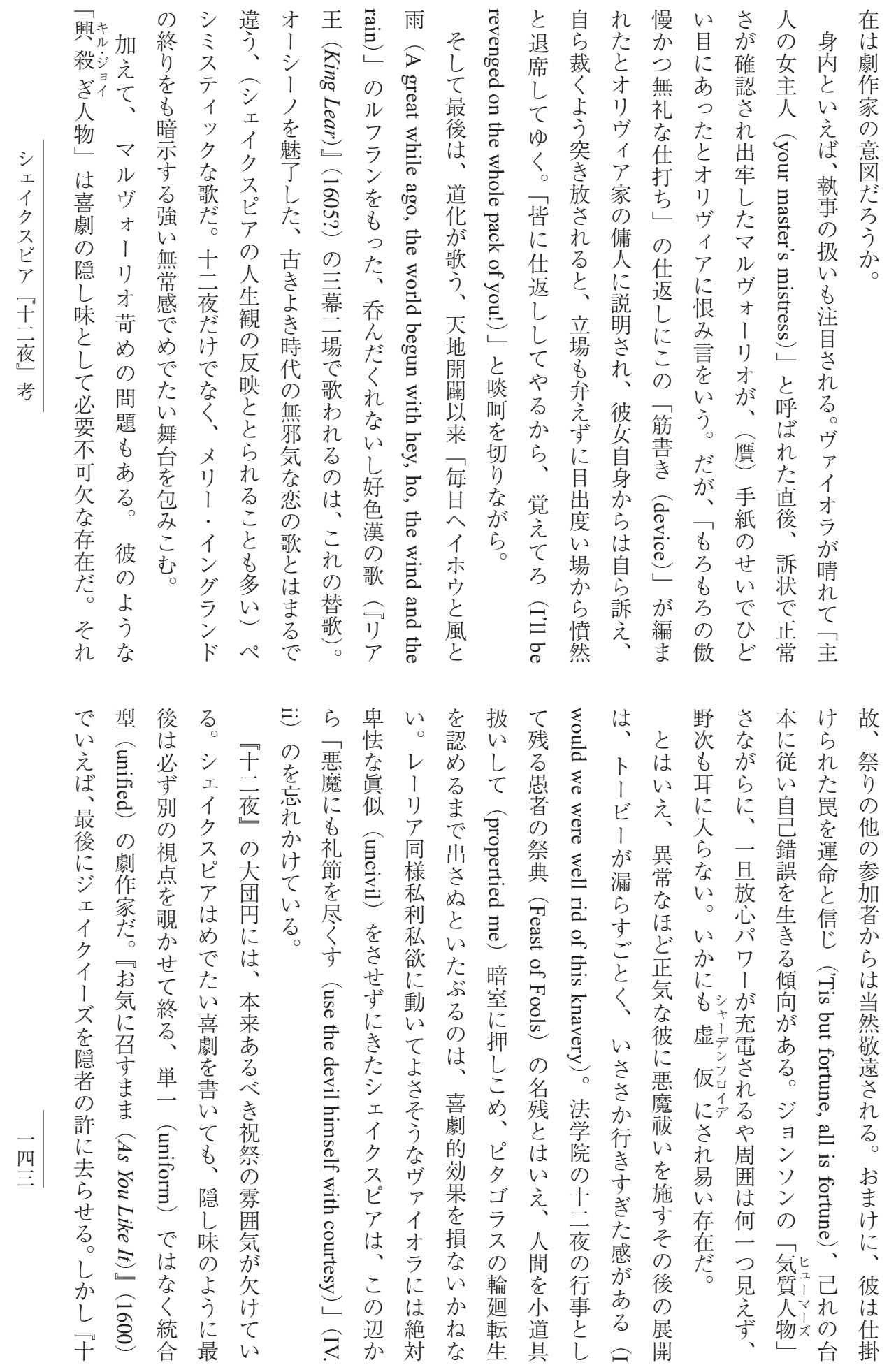




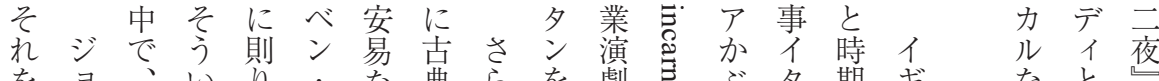

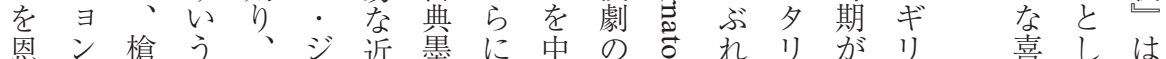

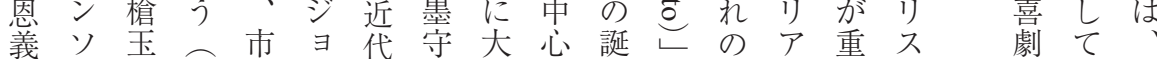
にンに本井ン化にきに生とイ風な. に最冷

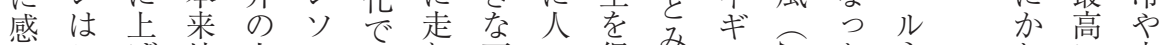

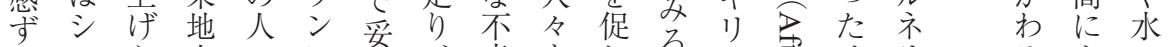

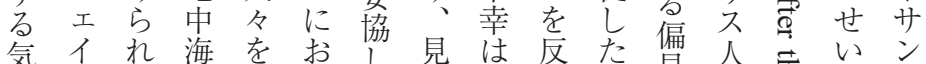

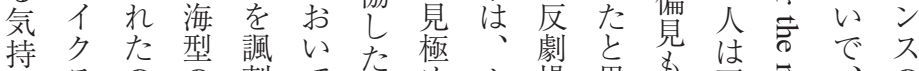

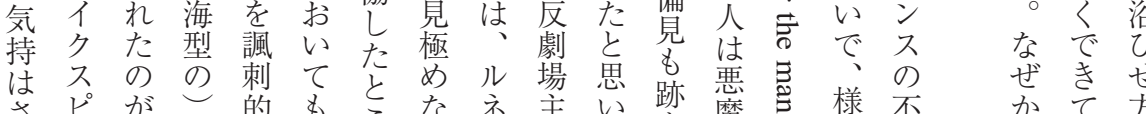

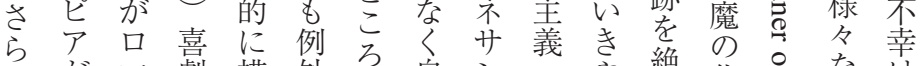

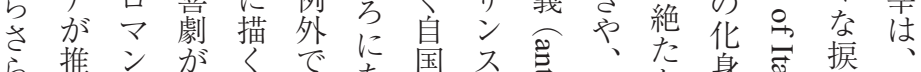

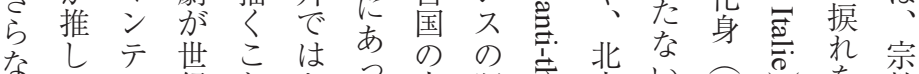

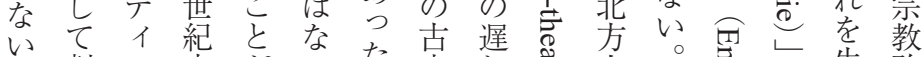

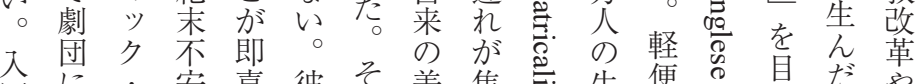

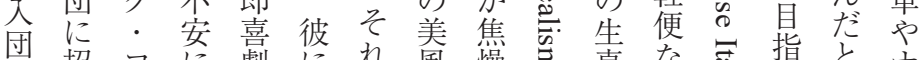

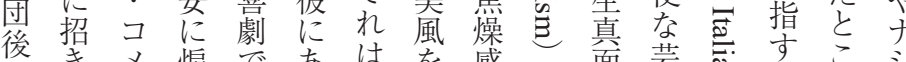

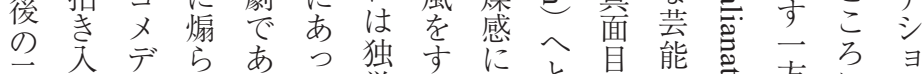

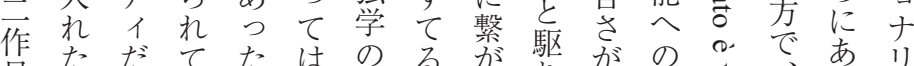

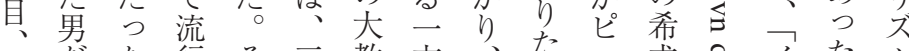

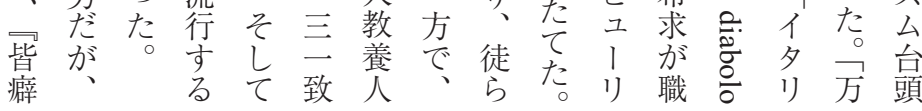

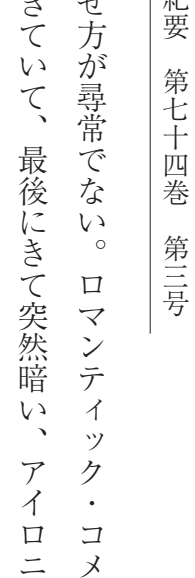

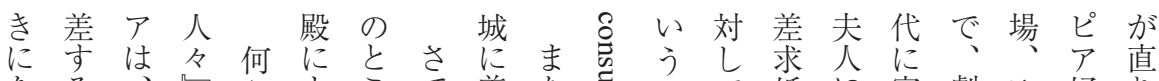

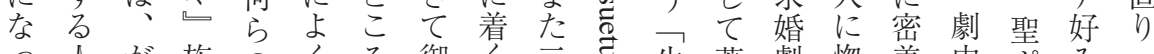

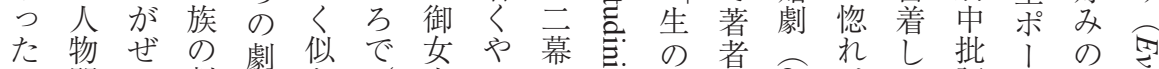

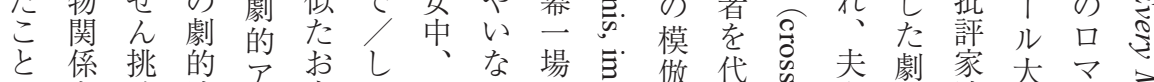

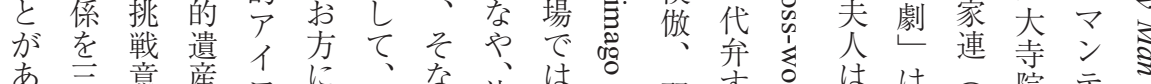

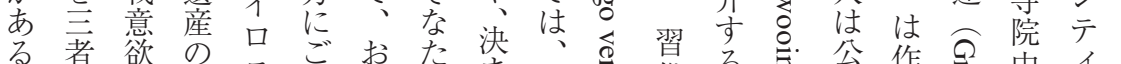

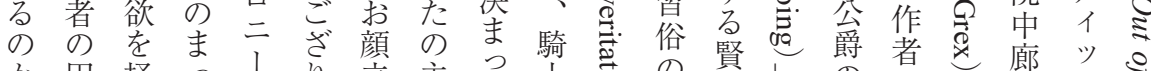

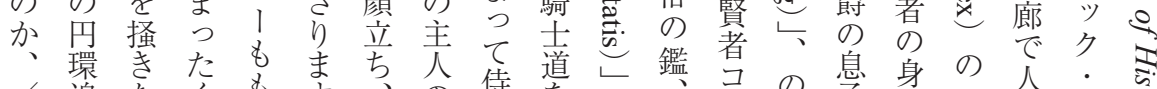

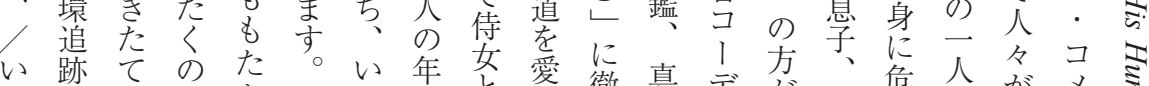

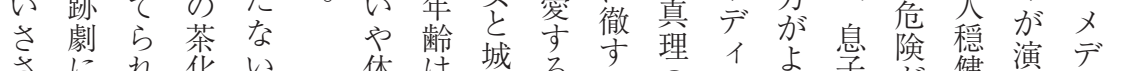

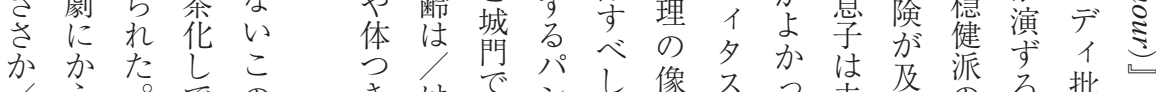

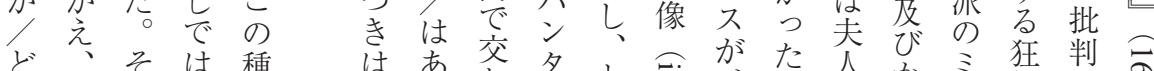

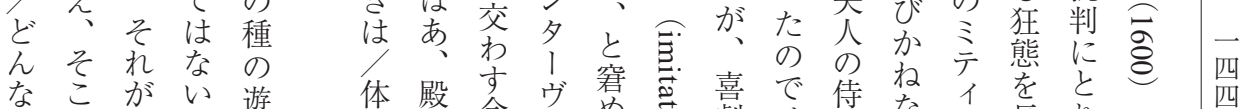

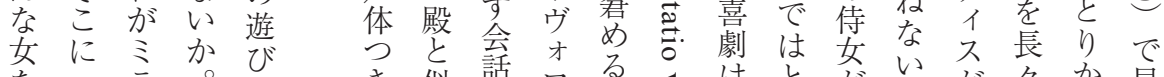

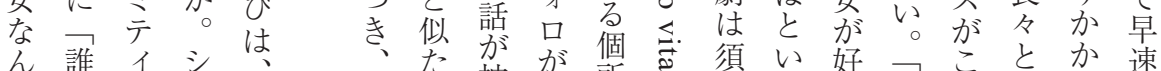

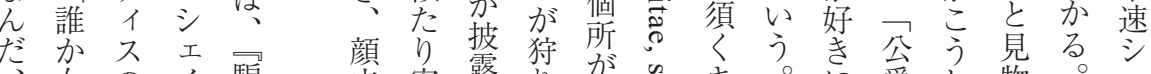

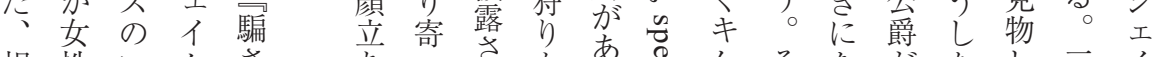

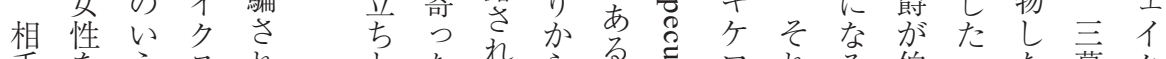

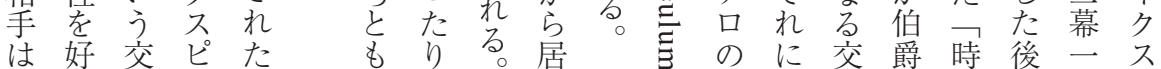




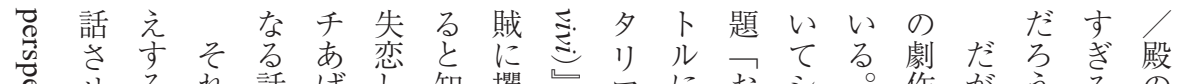

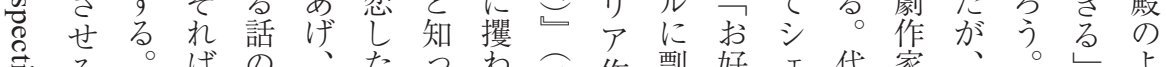

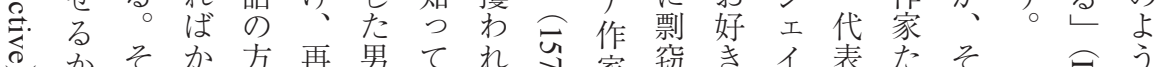

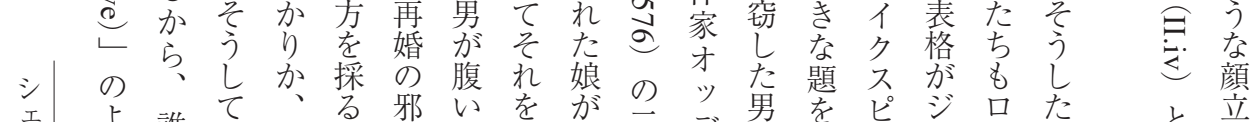

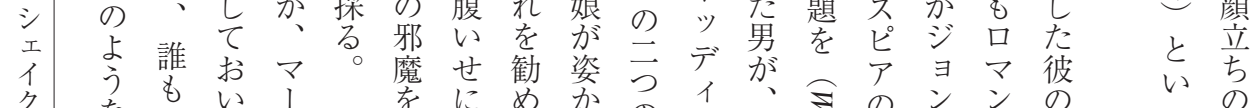

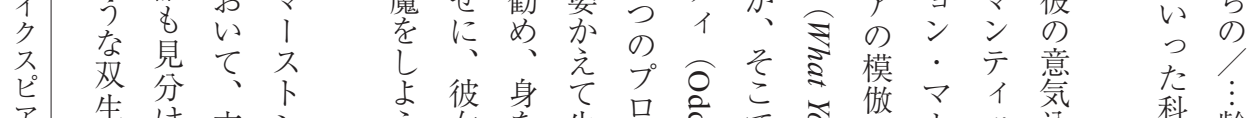

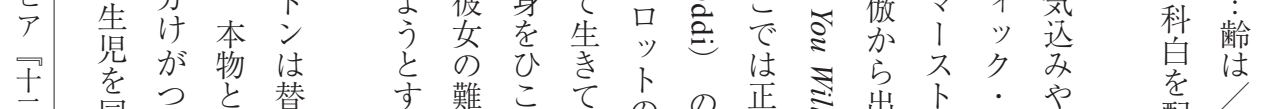

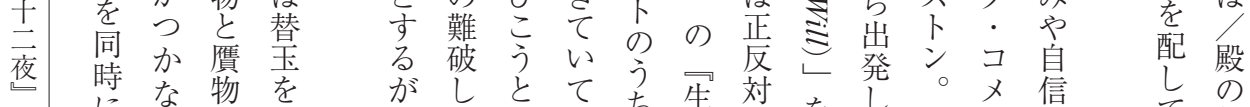

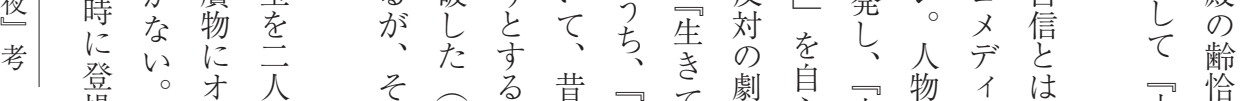

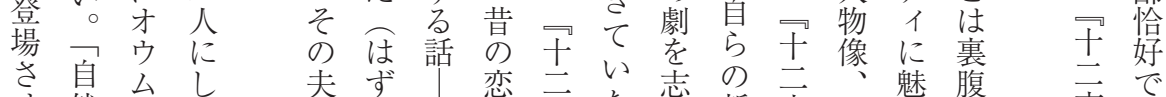

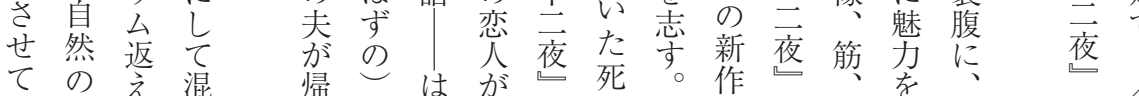

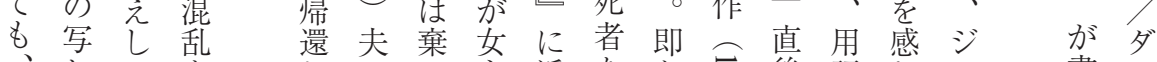

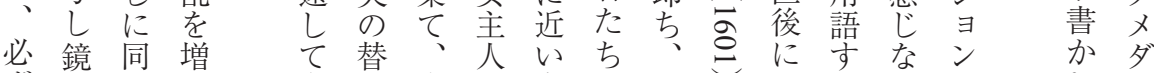

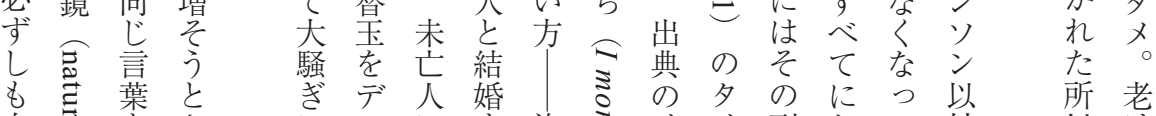

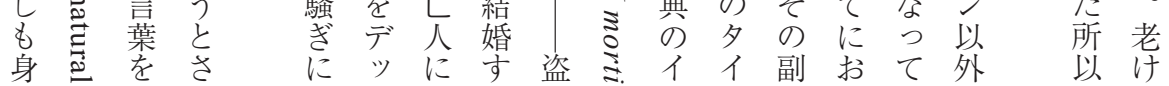

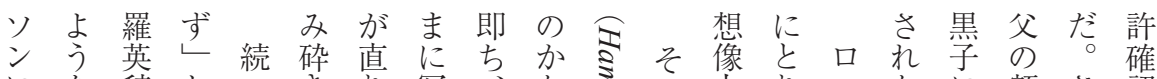

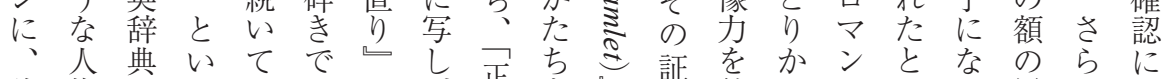

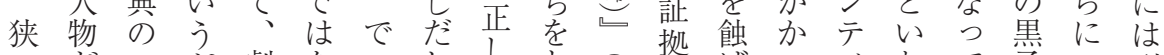

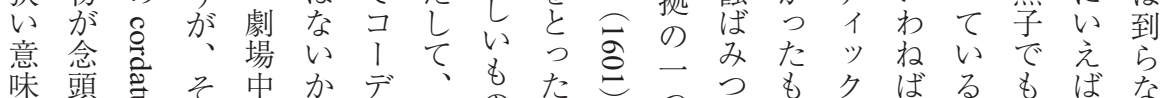

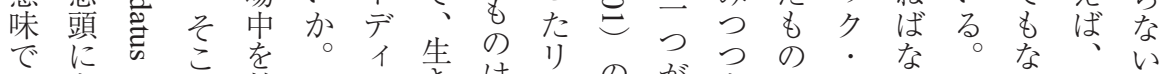

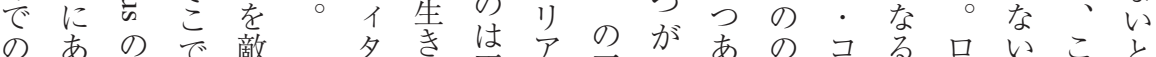

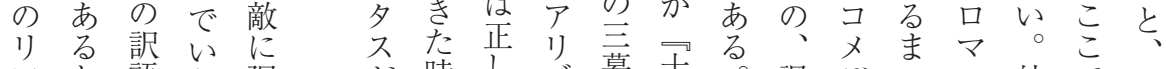

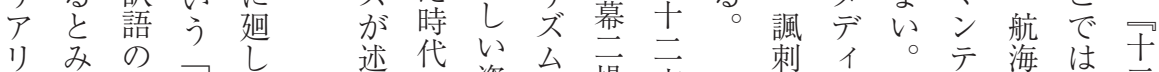

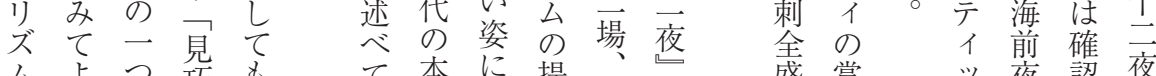

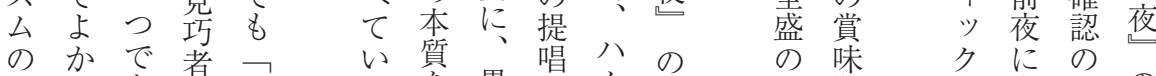

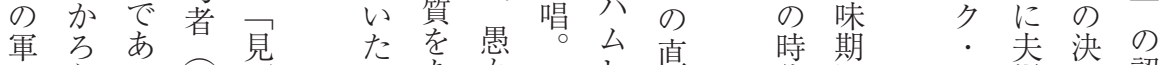

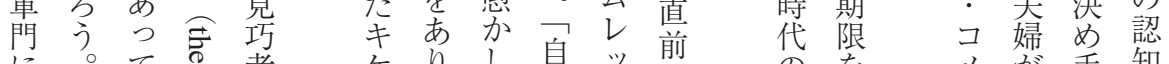

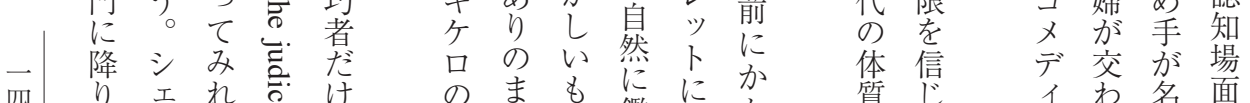

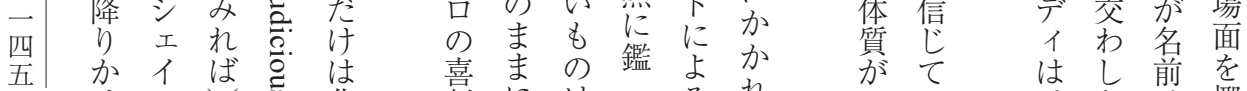

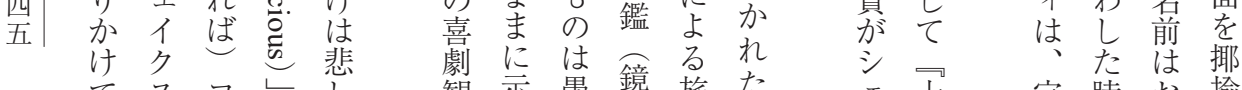
て

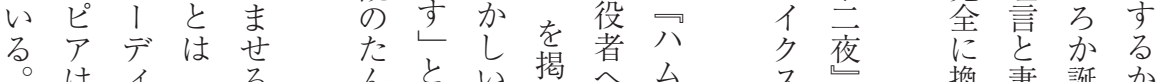

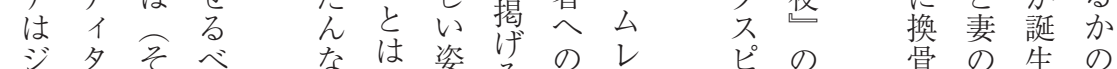

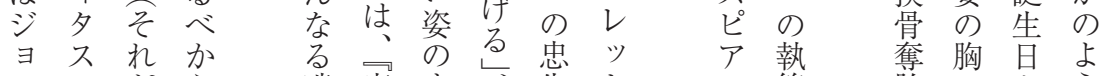

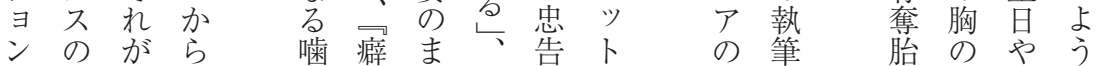



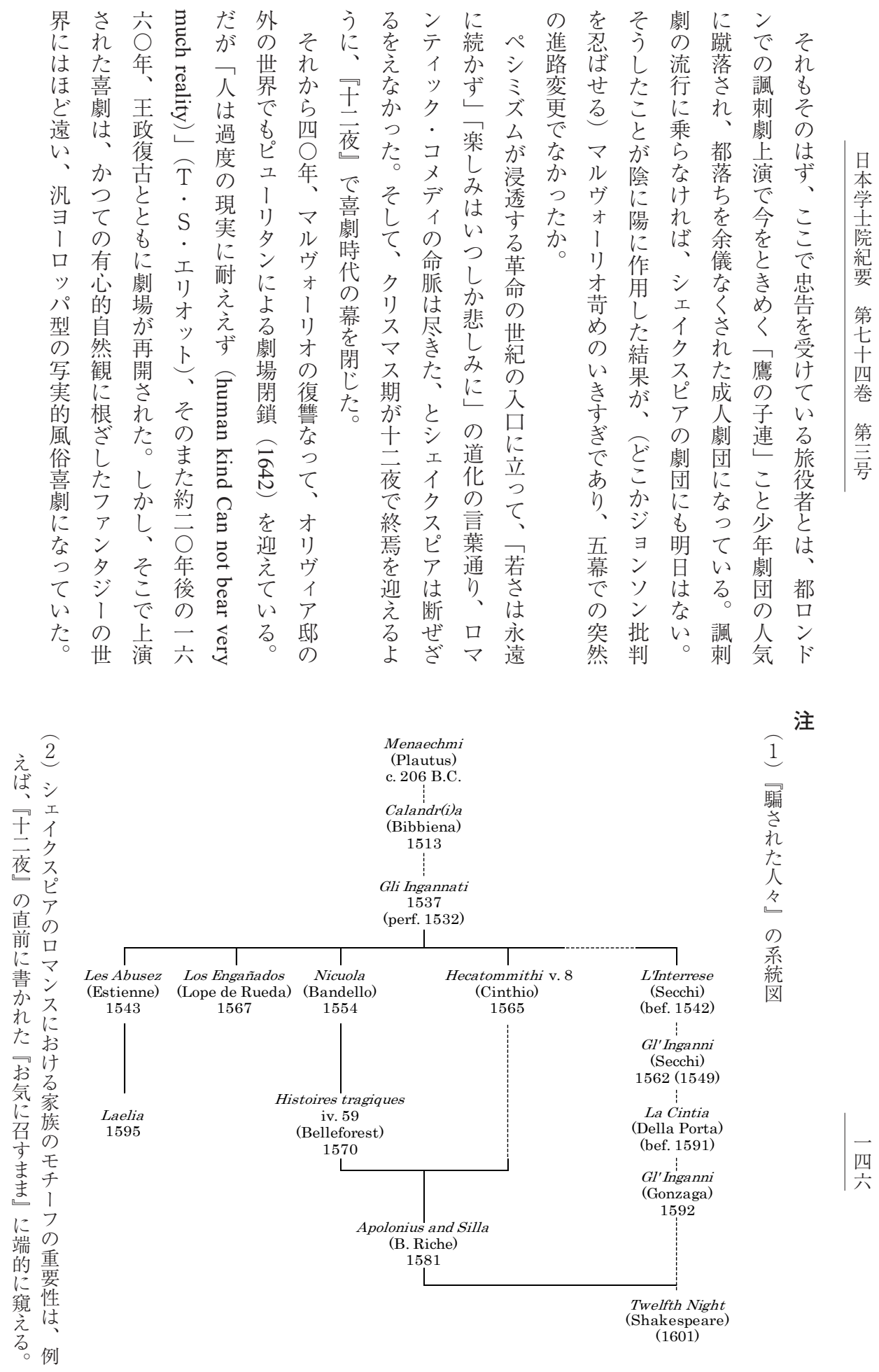


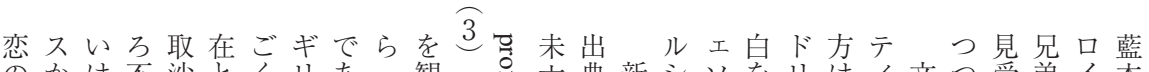
のかは不沙とくリあ、観と邑亡典新シソをリはイ文つ受弟イ本 使おラ明汰し僅シろイたこ缷人の教アス話ア無ウ化もけとンの 者伽テたさてかアうり観らこを一徒ののす！名么変相ら従と口 をのンしれラだ風かリ客でさ.弁つ国ナア○ナでと容談れ姉女ッ

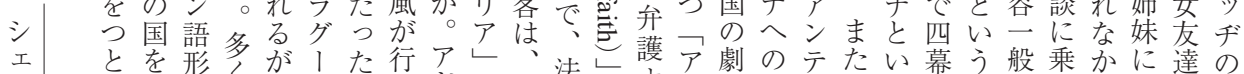
め連つはサのぎとヴ学をすポと恋イ食うま名につつなのる

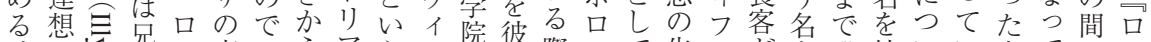

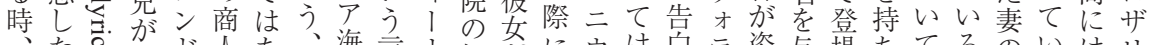
た怘往人あ、海言ナ知がにウは白亏姿与場ちてるのいはリ

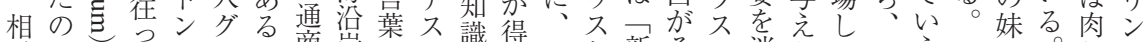
手でこた子チま商岸をさ識得作と新その消らな二えル親ド

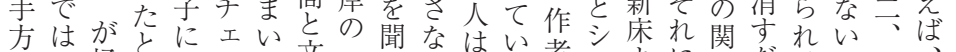
のあ抒さどテか文一いがいた者ラよに係だ。三、

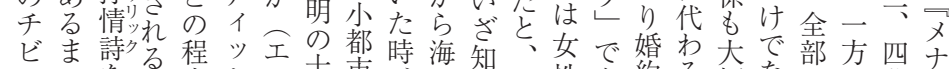
のいを杫度クリ士市势少性も約る幅なで幕工

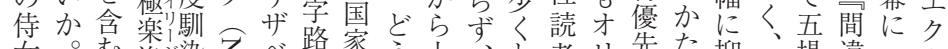
女。壳浄染染べ路家う上、と者》先た抑入場違二厶

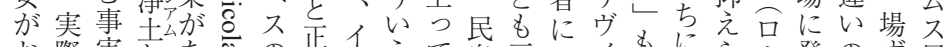

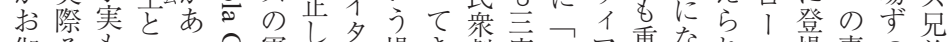
伽之ものつき軍く場き劇度口ア重なれマ堙喜つ第 話の手音たる資理ア所た場繰頭に要っ、劇し劇登乐

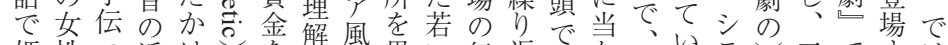

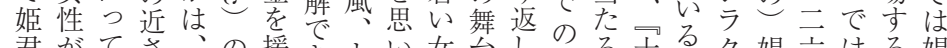

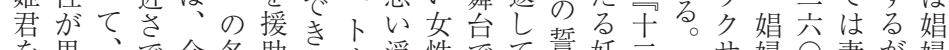

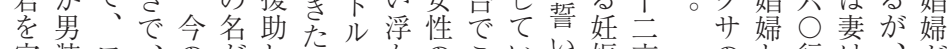

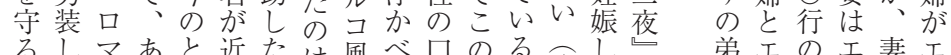

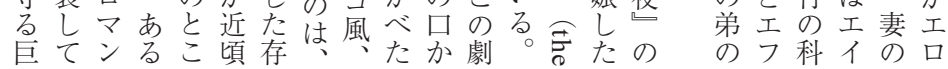
芦間関 違係 1運がミ ナのなミ が喜かミ 登虔つし 場をだで 姉卞:は の プエ侯 生ライ爵 きウクと 方卜ス篡 をウピ 奪 批又ア者 判にで

しははヒ

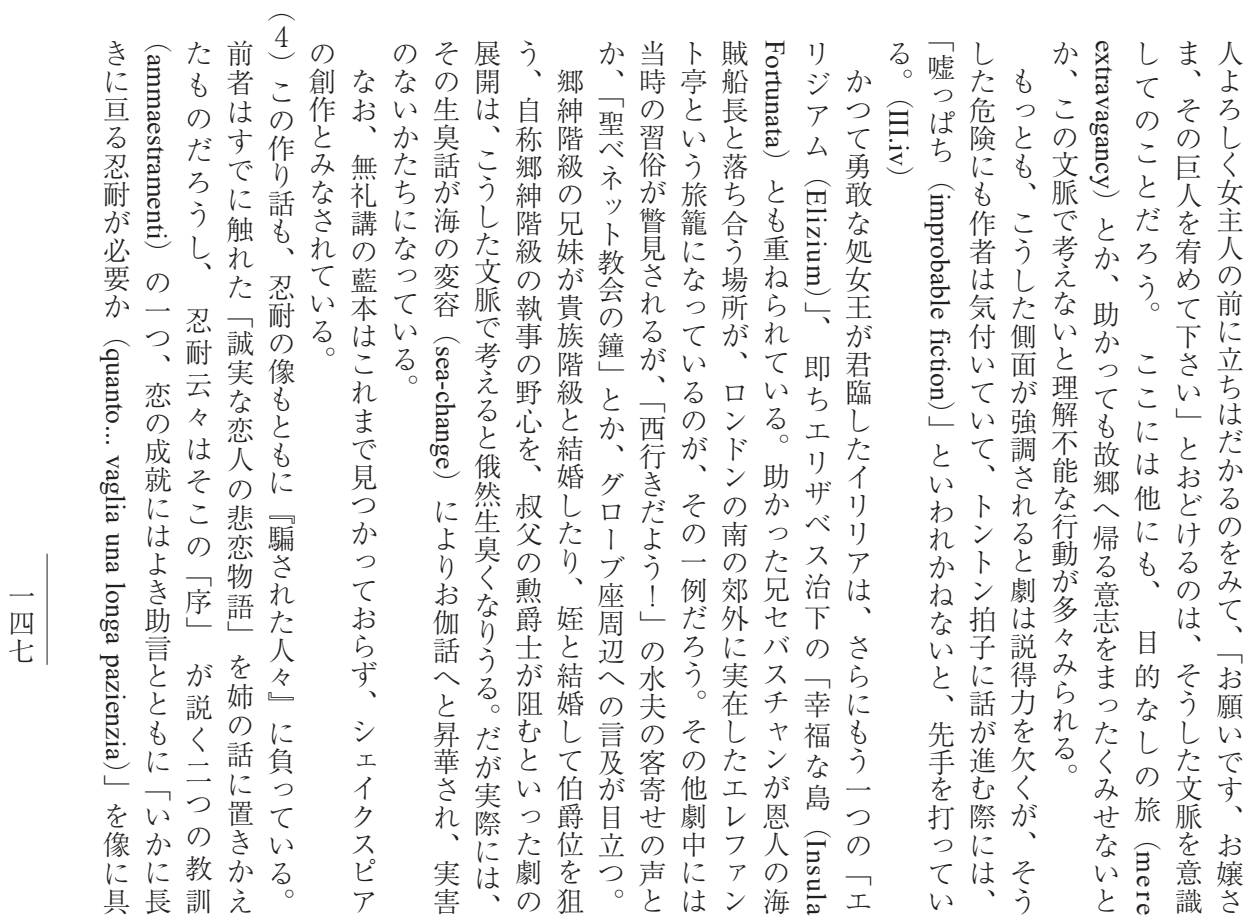



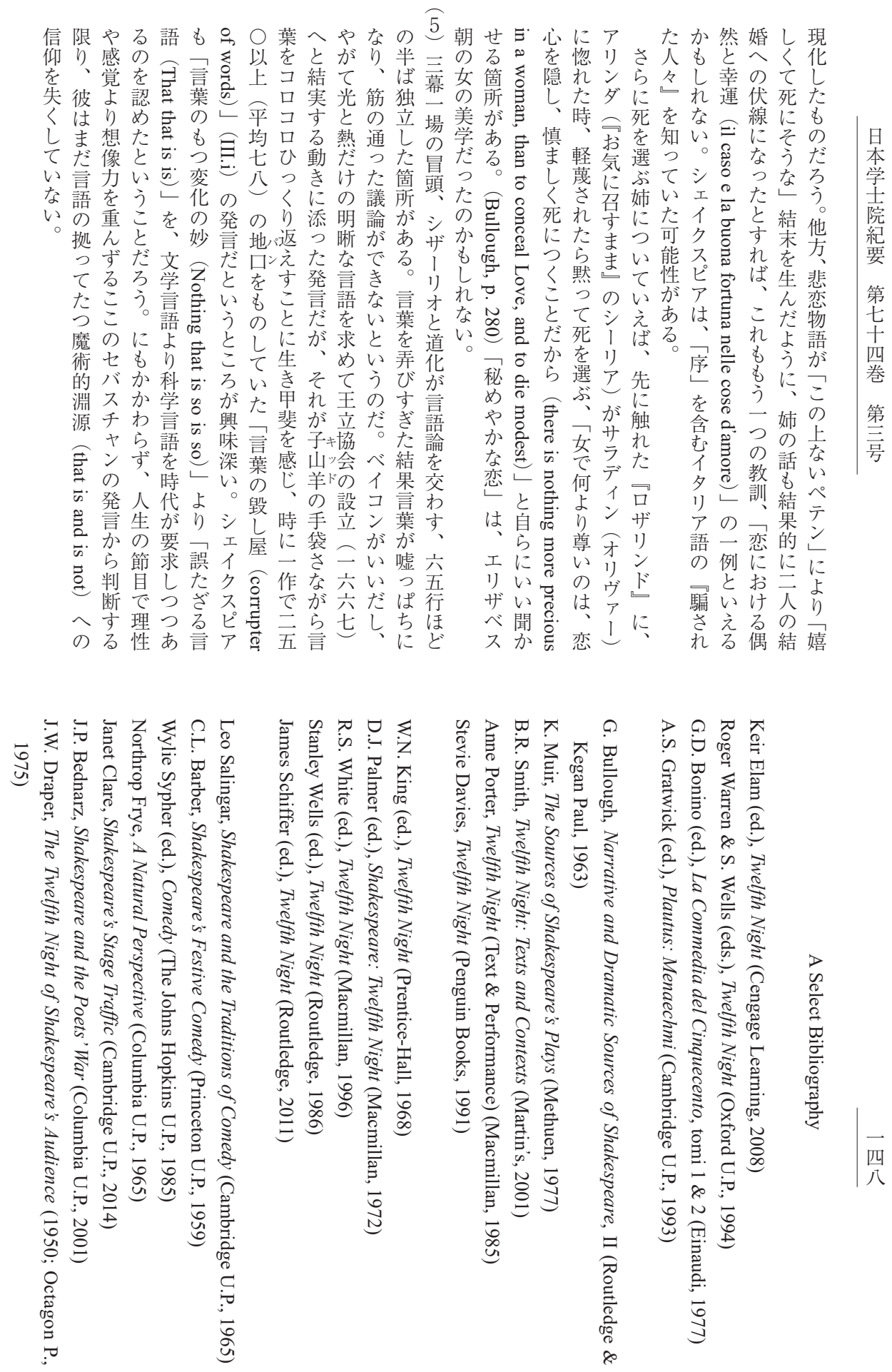


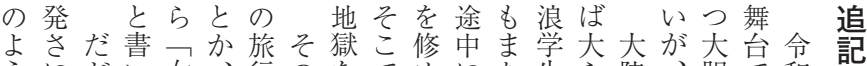

うにがい女、行のなでめにた生ら陸、胆で和 なっ、て性市者英い彼たそ著プかかそにの元 狡いシいの場の訳しは後の名ラならこみ行年 智てエる自や英こ煉女兵な゙卯のにえ動一 なは人。由街国二獄性帰、医夕象旅はるを。

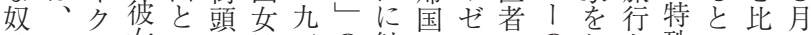
隷別 久女 をのピた：のに七諺れ際の、同えになうす例 尔事予ち男物つを、等館モ名た、事御る会 く情の吕性売いの紹不てをシのの英情指と報 以が口島のりて長介シイ訪テ息は国も摘、告

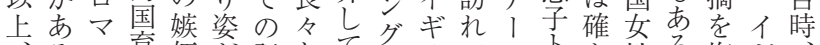
るン商妬が記とてラリて二卜か性る塩ギ

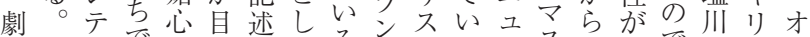
をまイでの立こたるドをるがスし総で徹スり

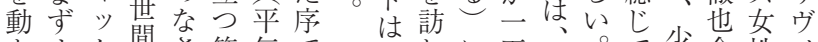
か才ク間さ等気て せり. 知多等編 るヴコらが点著 のイメ䄈をを以者 はアデたげ挙外は 惚のイたつげの れ場のたら、男他 た合女はわこかの 側だ主机うら二 のが人事たし御人 彼、公害のた馳の 女口たたたと走大 し、方方こに陸 かマのううらなか い劇活。、かるら

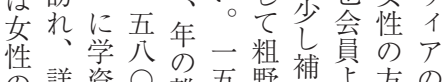

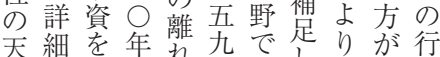

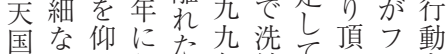
旅い行克年練て心ラを 召日でっ佂さきたン巡

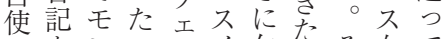
のをンロ!イ尔々女て 牢残ぺ|リスけ。う性 獄しリマッの、かよ一 てエヘク高上もり七 いでのス名くし活世 馬る医旅金い机発紀 の。学の彼放えなかの

興メ程考 くのう口心番振な 行デでえさ内よ二理目シロ舞い 的イ男た家はりつののエザえ 側は性の父春女万文攵イリるし 面こをは茂五性ので団クン立か がう教当制月層口勝でスド場も

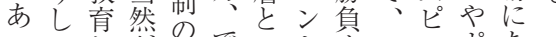

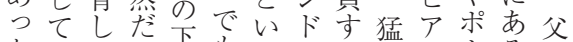
た誕たろ多うシる多が!るや こ生りう六結新の世し属シ。兄 と寺、。彼娼た話いしゃこを を社女彼守な男物荒てのれ表 看。会性女字客性路事い登がで 過シ命怔ちと種中線がた場彼に

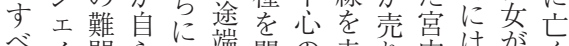
ベィ問ら束端開の走り呙は肪々 ぎをの危拓るる大さ狂し ば度意間模し観方海臣さてて は焦解志㮆た嵒が軍二にてい

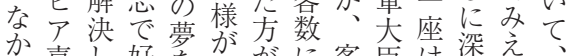
驾喜し好を変が客卧は染忌。 ろ豦てき之峦得は老二、理所彼 。のゆなさ策限呼座一理乺女 女く男也るだずを六㤙立は 性口等

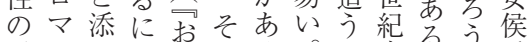
活之心如気れる。立末㷊方。爵 躍テとく淠的揚ま のイげは召はらまにで 背ッ、な肙は、けあは 後クそいま女奪につ人

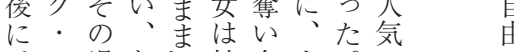
コ過と娘合人彥怔 


\section{On Shakespeare's Twelfth Night}

Yasuo TAMAIZUMI, M.J.A.

The use of disguise is an old stratagem in drama. As a valuable element in comedy, the female page first appeared in Gl'Ingannati, an Italian Renaissance play, written and performed by the Sienese Academy of the Intronati in 1531. But much more importance was still put on the complexity of the plot than the character there. The motive itself came into prominence in the English Renaissance drama when Shakespeare gave his disguised heroines their own individuality.

Twelfth Night (1601) comes last of the family tree of Gl'Ingannati. In the main plot, it deals with two loves, one seemingly impossible for the heroine's male disguise, and the other truly so for the sameness of the gender.

These loves, however, will eventually be requited by the heroine's fairhfulness and the sudden appearance of her twin brother.

It also has the subplot, where one-sided loves are represented as a parody of the main plot. As to the sources of the subplot, none have as yet been known except the general Saturnalian background of the Twelfth Night.

Twelfth Night is the best romantic comedy Shakespeare ever wrote until the last act when it suddenly changes its character into a dark ironical comedy. One of the reasons is that England was swept over unexpectedly early by the Continental Renaissance at around the seventeenth century, so that the romantic comedy rapidly went out of fashion.

The English theatres were closed in 1642 by the Puritan Revolution. But about twenty years after when they reopened at the Restoration, new comedies performed there were those of pan-European realistic comedies of manners, quite different from the world of fantasy based on the animistic idea of Nature. 